\title{
Review \\ Ranolazine: An Old Drug with Emerging Potential; Lessons from Pre-Clinical and Clinical Investigations for Possible Repositioning
}

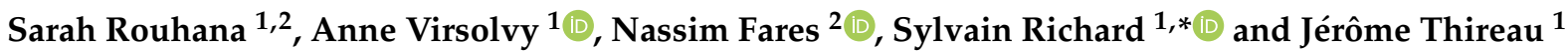 \\ 1 PhyMedExp, Université de Montpellier, Inserm U1046, CNRS UMR 9214, 34295 Montpellier, France; \\ sarah_rouhana89@hotmail.com (S.R.); anne.virsolvy@inserm.fr (A.V.); thireau.jerome@gmail.com (J.T.) \\ 2 Research Laboratory in Physiology and Physiopathology, University Saint Joseph, Beyrouth 10999, Lebanon; \\ nassim.fares@usj.edu.lb \\ * Correspondence: sylvain.richard@inserm.fr; Tel.: +33-4674-1-5241; Fax: +33-4671-5242
}

Citation: Rouhana, S.; Virsolvy, A.; Fares, N.; Richard, S.; Thireau, J. Ranolazine: An Old Drug with Emerging Potential; Lessons from Pre-Clinical and Clinical Investigations for Possible Repositioning. Pharmaceuticals 2022, 15, 31. https:// doi.org/10.3390/ph15010031

Academic Editor: Mary J. Meegan

Received: 11 October 2021

Accepted: 20 December 2021

Published: 25 December 2021

Publisher's Note: MDPI stays neutral with regard to jurisdictional claims in published maps and institutional affiliations.

Copyright: (c) 2021 by the authors. Licensee MDPI, Basel, Switzerland. This article is an open access article distributed under the terms and conditions of the Creative Commons Attribution (CC BY) license (https:// creativecommons.org/licenses/by/ $4.0 /)$.

\begin{abstract}
Ischemic heart disease is a significant public health problem with high mortality and morbidity. Extensive scientific investigations from basic sciences to clinics revealed multilevel alterations from metabolic imbalance, altered electrophysiology, and defective $\mathrm{Ca}^{2+} / \mathrm{Na}^{+}$homeostasis leading to lethal arrhythmias. Despite the recent identification of numerous molecular targets with potential therapeutic interest, a pragmatic observation on the current pharmacological R\&D output confirms the lack of new therapeutic offers to patients. By contrast, from recent trials, molecules initially developed for other fields of application have shown cardiovascular benefits, as illustrated with some anti-diabetic agents, regardless of the presence or absence of diabetes, emphasizing the clear advantage of "old" drug repositioning. Ranolazine is approved as an antianginal agent and has a favorable overall safety profile. This drug, developed initially as a metabolic modulator, was also identified as an inhibitor of the cardiac late $\mathrm{Na}^{+}$current, although it also blocks other ionic currents, including the hERG/Ikr K ${ }^{+}$current. The latter actions have been involved in this drug's antiarrhythmic effects, both on supraventricular and ventricular arrhythmias (VA). However, despite initial enthusiasm and promising development in the cardiovascular field, ranolazine is only authorized as a second-line treatment in patients with chronic angina pectoris, notwithstanding its antiarrhythmic properties. A plausible reason for this is the apparent difficulty in linking the clinical benefits to the multiple molecular actions of this drug. Here, we review ranolazine's experimental and clinical knowledge on cardiac metabolism and arrhythmias. We also highlight advances in understanding novel effects on neurons, the vascular system, skeletal muscles, blood sugar control, and cancer, which may open the way to reposition this "old" drug alone or in combination with other medications.
\end{abstract}

Keywords: persistent $\mathrm{Na}^{+}$current; hERG/IKr K ${ }^{+}$current; arrhythmia; vascular; neuronal; metabolism

\section{Introduction}

Ranolazine (Ranexa $\left.{ }^{\circledR}\right)$ is a piperazine derivative [RS-43285; (6)-N (2,6-dimethyl-phenyl)4[2-hydroxy-3(2-methoxy-phenoxy)propyl] 1-piperazine acetamide)] (Figure 1A) used as a second-line treatment in patients with stable or poorly controlled chronic angina pectoris and unresponsive to other drugs [1-3]. This non-hemodynamic anti-angina agent, patented in 1986 and approved by the Food and Drug Administration in 2006, is prescribed in the United States, Japan, and some European countries. However, ranolazine has other potential beneficial therapeutical effects in various cardiovascular pathologies, including post-operative, new-onset, paroxysmal, and chronic atrial fibrillation (AF), ventricular arrhythmias (VA), revascularization, coronary artery disease, diastolic and microvascular dysfunction, metabolic diseases, and diabetes [1,4]. A PubMed search by typing the word 'ranolazine' released more than 1100 references (1998-2021), showing the great interest this molecule has attracted due to its clinical potential and complex effects. Ranolazine indeed requires high doses to achieve an effect and could be considered a 'dirty' 
molecule. A low affinity for specific targets may account for the multiple outcomes and poorly understood action mechanisms. There is a trend in finding new uses for ranolazine (Table S1 in Supplementary Data), especially in diseases with unmet clinical needs. Recent data have shown that ranolazine can modulate the excitability of neurons in the peripheral nervous system, including the autonomic component, and the vascular system. The contribution of these effects to various potential benefits and limitations of ranolazine warrant further investigation. Here, we review the different clinical uses of ranolazine (Table S2 in Supplementary Data), its known mechanisms of action, and its potential for consideration in cardiac and other diseases.

A

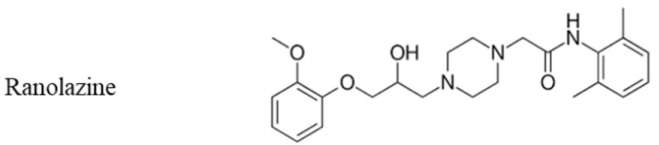

B

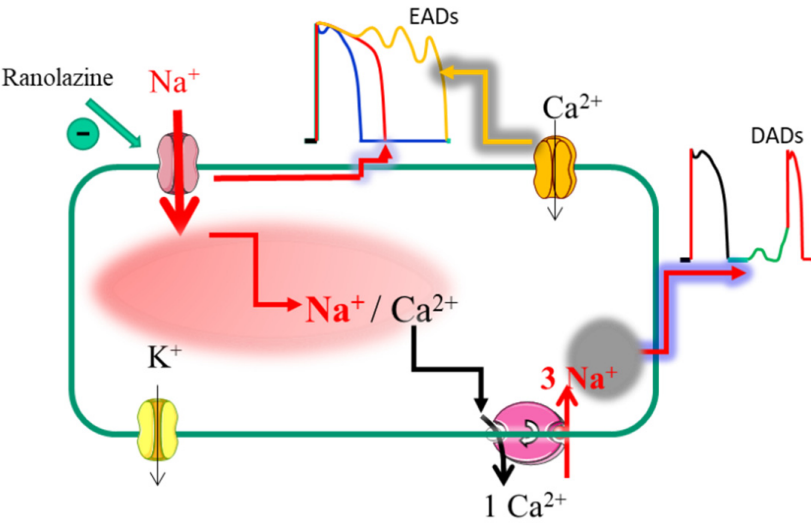

C

C57BL6 mouse 12 week-old, baseline
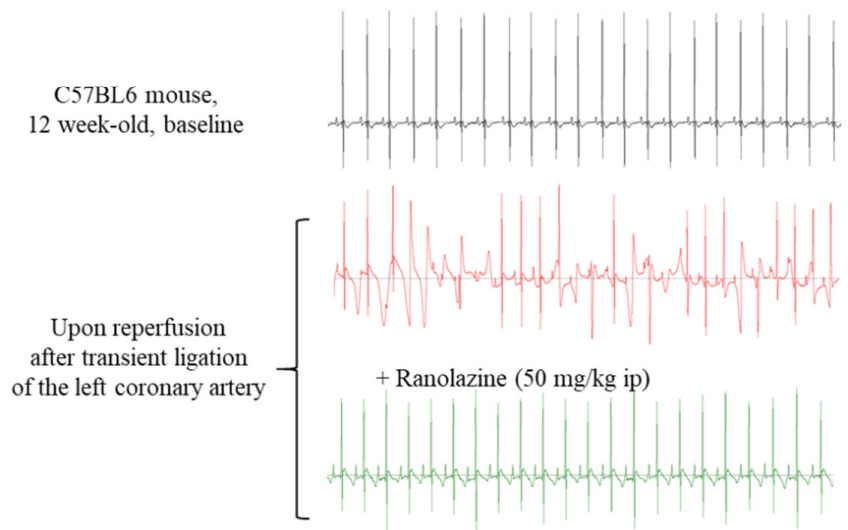

Figure 1. Benefits of $\mathrm{I}_{\mathrm{Na} \text {,late }}$ inhibition by ranolazine on cellular cardiac action potential (AP) and $\mathrm{Na}^{+} / \mathrm{Ca}^{2+}$ ion homeostasis, and antiarrhythmic effects. (A) Chemical structure of Ranolazine. (B) Cellular impact of the sustained entry of $\mathrm{Na}^{+}$caused by $\mathrm{I}_{\mathrm{Na} \text {,late }}$ in cardiomyocytes. Two mechanisms cooperate: (i) the transmembrane influx of $\mathrm{Na}^{+}$, which maintains depolarization during the plateau phase of the action potential and can generate a re-activation of the $\mathrm{Ca}^{2+}$ channels responsible for early after depolarisations (EADs); (ii) the increase in intracellular $\mathrm{Na}^{+}$, which promotes an increase in intracellular $\mathrm{Ca}^{2+}$ and the occurrence of $\mathrm{Ca}^{2+}$-dependent delayed after depolarizations (DADs). Ranolazine prevents both mechanisms by shortening the AP and decreasing intracellular $\mathrm{Na}^{+}$and $\mathrm{Ca}^{2+}$ in the presence of an $\mathrm{I}_{\mathrm{Na} \text {,late }}$ (C) Typical electrocardiograms, recorded in 12-week-old male C57BL6 mice under gas anesthesia (Isoflurane 2.5\%), during baseline conditions (upper panel) and after reperfusion following $25 \mathrm{~min}$ of ligation of the left coronary artery in the absence (middle panel) and in the presence of ranolazine (50 mg/kg i.p.) (lower panel) (unpublished personal data). 


\section{Ranolazine as an Antianginal and Anti-Ischemic Drug}

Ranolazine was first developed as an antianginal and anti-ischemic metabolic effector. Inhibiting fatty acid oxidation leads to a shift in myocardial energy production, from fatty acid oxidation to glucose oxidation, explaining ranolazine's beneficial effects on cardiac metabolism and improved exercise tolerance without affecting heart rate or blood pressure [5-7]. The beneficial mechanism of the action of ranolazine in angina pectoris has been challenging to elucidate and has only recently begun to be clarified. It may involve indirect normalization of ion homeostasis. Indeed, during ischemia, changes in the ion homeostasis of cardiomyocytes are immediate. Alterations involve intracellular $\mathrm{Na}^{+}, \mathrm{Ca}^{2+}$, and $\mathrm{H}^{+}$and extracellular $\mathrm{K}^{+}$[8-10]. In particular, an increase in the amplitude of a persistent or late $\mathrm{Na}^{+}$current $\left(\mathrm{I}_{\mathrm{Na}}\right.$,late $)$, as found in several pathological situations, is sufficient to prolong the duration of the action potential (AP) and increase the intracellular concentration of $\mathrm{Na}^{+}$[11]. $\mathrm{Na}^{+}$extrusion through the $\mathrm{Na}^{+}-\mathrm{K}^{+}$ATPase pump does not properly counterbalance the load of $\mathrm{Na}^{+}$, which increases intracellular $\mathrm{Ca}^{2+}$. The $\mathrm{Ca}^{2+}$ overload increases diastolic left ventricular (LV) pressure, causing a vicious cycle feedback loop on energy supply and demand, worsening angina pectoris. Indeed, the increase of intracellular $\mathrm{Ca}^{2+}$ in myocardial cells increases the tension of the diastolic wall and increases the end-diastolic pressure. The increase in the stiffness of the diastolic wall causes intra-myocardial vascular compression, which reduces blood flow and the supply of oxygen to the myocardium, then prevents ventricular filling [12]. In addition, an overload of $\mathrm{Ca}^{2+}$ can lead to cell damage and death if it is not corrected [13]. The increase in $\mathrm{I}_{\mathrm{Na}}$, late may be the main contributor to the phenomena observed in ischemia and hypoxia [14-16], paving the way for clinical trials showing therapeutic benefits of ranolazine [17].

Blocking of $\mathrm{I}_{\mathrm{Na} \text {, late }}$ is the proposed mechanism in the proven efficacy and clinical indication for ranolazine treatment for stress angina. Blocking $\mathrm{I}_{\mathrm{Na} \text {, late }}$ reduces intracellular $\mathrm{Na}^{+}$, $\mathrm{Na}^{+}$-induced $\mathrm{Ca}^{2+}$ overload and the subsequent deleterious effects on the diastolic pressure of the LV that exacerbate angina pectoris $[2,3,18]$. Effective concentrations have little or only minimal impacts on heart rate and blood pressure [19], leading to the hypothesis that ranolazine exerts its cardioprotective effects by a mode of action primarily separate from that of typical antianginal drugs such as $\mathrm{Ca}^{2+}$ channel antagonists, $\beta$-adrenergic receptor antagonists, and nitrates [17,20-22]. Experimental investigations showed that the $\mathrm{Na}_{\mathrm{v}}$ channel agonist Anemone Toxin (ATX-II) mimics the effects of ischemia/reperfusion to increase intracellular concentrations of $\mathrm{Na}^{+}$and $\mathrm{Ca}^{2+}$ [21]. Ranolazine could maintain coronary flow near normal levels during exposure to ATX-II. Therefore, besides its metabolic effect, ranolazine has been considered an $\mathrm{I}_{\mathrm{Na}}$, late blocker (i.e., up to 40 -fold more specific for $\mathrm{I}_{\mathrm{Na} \text {, late }}$ than $\mathrm{I}_{\mathrm{Na} \text {,peak }}$ current, depending on models and conditions) [23]. Overall, these latter properties contributed to providing ranolazine with the status of an antiarrhythmic molecule (Table S1 in Supplementary Data).

\section{Ranolazine as an Antiarrhythmic Drug}

\subsection{Ranolazine Has Multiple Ion Channel Effects}

The electrophysiological effects of ranolazine were questioned early, mainly because of the worry of potential impacts on the QT interval in patients with severe chronic angina [17]. Ranolazine has multi-channel blocking effects, similar to those observed after chronic amiodarone, yet ranolazine has a much lower risk of Torsades de Pointes (TdP) than amiodarone $[18,24,25]$. Ranolazine inhibits the delayed rectifying potassium current $\left(\mathrm{I}_{\mathrm{Kr}}\right)$ (Kv11.1 channel encoded by the KCNH2 gene or HERG) and the L-type calcium channel current $\left(\mathrm{I}_{\mathrm{Ca}, \mathrm{L}}\right)$ at concentrations slightly higher than those required to inhibit peak $\mathrm{Na}$ channel current $\left(\mathrm{I}_{\mathrm{Na} \text {,peak }}\right)$, and has a modest and self-limited effect on the QT interval [26]. A comparative electrophysiological investigation performed in isolated canine $\mathrm{LV}$ myocytes indicated that ranolazine inhibits different currents with the following $\mathrm{IC}_{50}: 11.5 \mu \mathrm{M}$ for $\mathrm{I}_{\mathrm{Kr}}, 5.9 \mu \mathrm{M}$ for $\mathrm{I}_{\mathrm{Na}, \text { late, }}, 50 \mu \mathrm{M}$ for late $\mathrm{I}_{\mathrm{Ca}, \mathrm{L}}, 296 \mu \mathrm{M}$ for peak $\mathrm{I}_{\mathrm{Ca}, \mathrm{L}}$, and $91 \mu \mathrm{M}$ for $\mathrm{I}_{\mathrm{NCX}}(\mathrm{NCX}$ for $\mathrm{Na}^{+} / \mathrm{Ca}^{2+}$ exchanger) while they found no effect on $\mathrm{I}_{\mathrm{to}}$ and $\mathrm{I}_{\mathrm{K} 1}[18]$. 
Despite multiple molecular targets, the vast majority of clinical studies have reported good safety and tolerability of ranolazine, yet with some contraindications., mainly dizziness, headache, nausea, debility, constipation, and a variety of side effects that are not specific and most often shared by other drugs [4,27-33]. Hence, many clinical trials found that short- and long-term treatments with ranolazine are safe despite a modest QT lengthening effect $[23,28,29,34]$. Administration in patients with a family history of long QT syndrome or known prolonged QT interval may be contra-indicated. The relative safety of ranolazine may relate to its ability to decrease $\mathrm{I}_{\mathrm{Ca}, \mathrm{L}}$ at concentrations close to those inhibiting $\mathrm{I}_{\mathrm{Kr}}$ in addition to $\mathrm{I}_{\mathrm{Na}}$, late, thus producing offsetting effects on repolarization at doses above $20 \mu \mathrm{M}[26,35,36]$. Ranolazine's multiple ion channel effects may support its "self-limitation" to trigger TdP [18].

As ranolazine does not trigger TdP despite its QT lengthening effect, clinical studies investigated its antiarrhythmic efficacy because of its interesting electrophysiological effects, including a significant blocking impact on $\mathrm{I}_{\mathrm{Na}}$,late. Ranolazine could suppress early afterdepolarizations (EADs) and reduce transmural dispersion of repolarization, suggesting antiarrhythmic activity [18]. Conversely, by normalizing $\mathrm{Ca}^{2+}$ homeostasis and repolarization heterogeneity, ranolazine could prevent malign VAs in the dog model of chronic atrioventricular block [37]. This trend was initially observed in several experimental models of long QT syndrome (LQT1, LQT2, and LQT3) [38-40] and then in patients with LQT3 in whom ranolazine (starting from $1 \mathrm{mg} / \mathrm{mL}$ ) shortened QTc without modifying the conduction time (PR and QRS) [41]. The benefit of $\mathrm{I}_{\mathrm{Na}}$,late blocking effect by ranolazine should not be reduced to those pathologies involving specific mutations in $\mathrm{Na}_{\mathrm{V}}$ isoforms $[42,43]$, since $\mathrm{I}_{\mathrm{Na}}$,late also develops in several pathological and pharmacological cardiovascular conditions, including bradycardia, myocardial ischemia, reperfusion injury, and heart failure (HF) with nefast consequences on morbidity and mortality [22].

\subsection{Clinical Evidence of Antiarrhythmic Benefits}

The MERLIN-TIMI 36 trial was the first study to assess ranolazine's antiarrhythmic effect (documented by electrocardiogram, ECG) in 6345 patients with non-ST-segment elevation acute coronary syndrome and moderate to high risk for death or recurrent ischemic events [44]. The addition of ranolazine to standard treatment was ineffective in reducing major cardiovascular events. However, ranolazine significantly suppressed supraventricular tachyarrhythmia and reduced new-onset AF by $30 \%$. In addition, subsequent analysis showed that the overall burden among patients with paroxysmal AF tended to be lower with ranolazine than with placebo, with fewer AF-related adverse events [45]. Indeed, overall, patients assigned to ranolazine had a trend towards fewer episodes of AF (75 (2.4\%) vs. $55(1.7 \%)$ patients, $p=0.08)$ from ECG during the seven first days after randomization. The pattern of new-onset AF differed between the ranolazine vs. placebo group: clinically insignificant AF (five patients in ranolazine vs. seven in placebo), paroxysmal AF (18 vs. 48 patients), and predominantly chronic AF ( 28 vs. 20 patients, three-way $p<0.01$ ). Among patients with a paroxysmal AF pattern, the overall burden was lower with ranolazine than with placebo (median 4.4 vs.16.1\%, $p=0.015$ ). Over the median 1-year follow-up, fewer patients treated with ranolazine experienced an AF event than placebo (2.9 vs. 4.1\%, RR $0.71, p=0.01)$. Many studies confirmed this trend with ranolazine used alone [46] or in combination with amiodarone/dronedarone [47-49] or ivabradine [50]. Short treatment with ranolazine also prevents AF following coronary artery bypass graft and valve surgery [51] and is more effective than amiodarone in preventing AF following coronary artery bypass surgery. Ranolazine can also be used for acute termination of new or paroxysmal AF as a "pill in the pocket" drug. In the RAFFAELLO trial, ranolazine prolonged the time to AF recurrence after successful electrical cardioversion and reduced AF recurrences [52].

Compared with the abundant data on ranolazine utility and efficacy in AF of different etiologies, only a few clinical studies investigated its use in ventricular rhythm disturbances. In the MERLIN-TIMI 36 trial, ranolazine reduced non-sustained ventricular tachycardia (VT) (i.e., at least eight successive abnormal ventricular complexes). The incidence of 
supraventricular arrhythmias was also reduced [44]. More recently, in a small cohort of patients with documented symptomatic premature ventricular contraction, ranolazine successfully reduced ventricular bigeminy by $80 \%(p<0.001)$, ventricular couplets by $78 \%(p<0.001)$, and finally VT by $91 \%(p<0.001)$ in a dose-dependent manner, underlying the need for a large, prospective randomized study [31].

In patients with drug-refractory shocks delivered by implantable cardioverter-defibrillator (ICD), ranolazine reduced VT burden and ICD shocks in 11/12 patients [53]. By contrast, a recent study in patients with ICD showed that ranolazine did not significantly reduce the incidence of VT, ventricular fibrillation (VF), or death in high-risk patients. However, in the last, the investigators highlighted that this study was underpowered to detect a difference in the primary endpoint (death). Nevertheless, in pre-specified secondary endpoint analyses, ranolazine administration was associated with a significant reduction in recurrent VT or VF requiring ICD therapy, without evidence for increased mortality [54]. In parallel with clinical evidence supporting antiarrhythmic effects (Table S2 in Supplementary Data), the mode(s) of action of ranolazine has been further explored in pre-clinics from biophysics to molecular, cellular, and in vivo electrophysiology to attempt to reveal its secrets.

\subsection{Antiarrhythmic Mechanisms at the Ventricular Level}

Antzelevitch's group revealed significant antiarrhythmic effects and the main targets of ranolazine. This drug exhibits antiarrhythmic action within its therapeutic range as an antianginal agent (i.e., 2-6 $\mu \mathrm{M}$ ) [18]. Tonic blockade of $\mathrm{I}_{\mathrm{Na} \text {, late }}$ is central at the ventricular level, while use-dependent inhibition of peak $\mathrm{I}_{\mathrm{Na}}$ and $\mathrm{I}_{\mathrm{Kr}}$ may underlie the atrial effects. It is worth noting that although a block of the peak $\mathrm{I}_{\mathrm{Na} \text {,late }}$ is more robust in the atria than the ventricles in dogs, fast pacing rates and depolarized resting membrane potential can induce substantial inhibition of $\mathrm{I}_{\mathrm{Na}}$, both peak and late, with class I/B antiarrhythmic characteristics in ventricular preparations $[35,55]$.

In normal conditions, cardiac voltage-gated $\mathrm{Na}^{+}$channels $\left(\mathrm{Na}_{\mathrm{v}}\right)$ open quickly and transiently to support the fast AP upstroke and then inactivate relatively quickly (milliseconds scale). Among the different $\mathrm{Na}_{\mathrm{v}}$ isoforms (from 1.1 to 1.8), $\mathrm{Na}_{\mathrm{v}} 1.5$ encoded by the $S C N 5 A$ gene is the main $\mathrm{Na}_{\mathrm{v}}$ channel in the heart [56,57]. This isoform generates the cardiac $\mathrm{I}_{\mathrm{Na} \text {,late, yet }} \mathrm{Na}_{\mathrm{v}} 1.8$, encoded by the $S C N 10 \mathrm{~A}$ gene, may also be involved in cardiac conduction and occurrence of VA [58-61]. A tiny $\mathrm{I}_{\mathrm{Na}}$ fraction (less than $0.1-1 \%$ of the global peak $\mathrm{I}_{\mathrm{Na}}$ amplitude) can persist in some pathophysiological situations and is referred to as $\mathrm{I}_{\mathrm{Na} \text {, late }}[62-64]$. $\mathrm{I}_{\mathrm{Na} \text {, late }}$ can last for several hundreds of milliseconds after the peak of $\mathrm{I}_{\mathrm{Na}}$. The evidence of a role for $\mathrm{I}_{\mathrm{Na} \text {,late }}$ in arrhythmogenesis was first derived from experiments on rat ventricular myocytes in hypoxic conditions $[14,65,66]$. This property, thus, provides ranolazine the status of a potential antiarrhythmic molecule as illustrated in (Figure $1 \mathrm{C}$ ). Indeed, $\mathrm{I}_{\mathrm{Na} \text {, late }}$ promotes abnormal automaticity and arrhythmia via at least two distinct mechanisms.

The first pro-arrhythmogenic function of $\mathrm{I}_{\mathrm{Na} \text {, late }}$ occurs at the cardiomyocyte's membrane compartment level, promoting prolonged depolarization throughout the cardiac AP plateau and providing a substrate for EADs [67]. The AP lengthening lengthens the QT interval of the ECG, initiates and perpetuates re-entry mechanisms until VT and TdP $[68,69]$. Typically, mutations in the SCN5A, associated with type 3 prolonged QT (LQT3) syndrome, slow inactivation of $\mathrm{Na}_{\mathrm{V}}$ channels and promote $\mathrm{I}_{\mathrm{Na} \text {,late }}$ [70]. A study in HEK cells expressing the $\mathrm{Na}^{+}$channel R1623Q mutation responsible for LQT3 syndrome showed $\mathrm{I}_{\mathrm{Na} \text {,late }}$ inhibition at low ranolazine concentrations [55]. In long QT syndromes (LQT1, LQT2, and LQT3), ranolazine efficiently suppresses TdP by normalizing repolarization stability and dispersion in several experimental models [23]. Ranolazine also efficiently reduces TdP triggering by xenobiotics, promoting the HERG blocking effect [37,38,71-73].

Ranolazine significantly reduces AP duration and repolarization instability in ventricular cells. However, it has no significant effects on the resting membrane potential in different models (canine ventricular cardiomyocytes, guinea pig papillary muscles and ventricular myocyte, canine atrial tissue, and Purkinje fibers) $[18,74,75]$. Ranolazine probably 
does not affect $\mathrm{I}_{\mathrm{K} 1}$ in ventricular and atrial cardiomyocytes [18,75]. Ranolazine-mediated AP duration decrease in ventricular cells is primarily due to significant inhibition of $\mathrm{I}_{\mathrm{Na} \text {,late }}$ current, and $\mathrm{I}_{\mathrm{Kr}}$, yet at different doses $\left(\mathrm{IC}_{50} \sim 6 \mu \mathrm{M}\right.$ for late $\mathrm{I}_{\mathrm{Na}}$ and $12 \mu \mathrm{M}$ for $\left.\mathrm{I}_{\mathrm{kr}}\right)[18,76]$. Depending on the cell type, the regional expression heterogeneity and the respective contribution of these currents on AP duration is a significant ranolazine asset. In cells with high $\mathrm{I}_{\mathrm{Na} \text {, late }}$ expression, and long AP duration (e.g., Purkinje and M cells), ranolazine shortens AP duration more efficiently, dose- and frequency-dependently [77-79]. Reduced outward conductance such as $\mathrm{I}_{\mathrm{Kr}}$ currents favors this effect [71]. It is especially true when the AP duration is pharmacologically lengthened by HERG blocking (human Ether-à-go-go-Related Gene) channel drugs by blockers of $\mathrm{Na}^{+}$channel inactivation, such as the ATX II, or during angiotensin treatment. In these conditions, ranolazine drastically shortens AP duration and reduces the dispersion of ventricular repolarization and beat-to-beat variability of AP duration $[18,37,76,80-82]$, and reduces risk factors for promotion of EADs and cardiac death following arrhythmias [83,84].

The second pro-arrhythmogenic impact of $\mathrm{I}_{\mathrm{Na} \text {,late }}$ involves intracellular $\mathrm{Na}^{+}$accumulation in the cytoplasm (Figure 1B). The rise in cytoplasmic $\mathrm{Na}^{+}$fuels intracellular $\mathrm{Ca}^{2+}$ overload via the $\mathrm{Na}^{+} / \mathrm{Ca}^{2+}$ exchanger (NCX) activity. Spontaneous sarcoplasmic reticulum (SR) $\mathrm{Ca}^{2+}$ release $\left(\mathrm{Ca}^{2+}\right.$ sparks) through the ryanodine receptor RyR2 can thus generate cytoplasmic $\mathrm{Ca}^{2+}$ waves as seen, for example, in HF or catecholaminergic polymorphic ventricular tachycardia [85]. Likewise, $\mathrm{Ca}^{2+}$ leakage from the SR is also involved in atrial arrhythmia (as AF) [86]. In these conditions, the NCX activated by the $\mathrm{Ca}^{2+}$ waves produces an electrogenic depolarizing $\mathrm{Na}^{+}$current $\left(\mathrm{I}_{\mathrm{ti}}\right)$ that enables firing of $\mathrm{I}_{\mathrm{Na}}$, spontaneous $\mathrm{AP}$, delayed after-depolarizations (DADs), and triggered activity [11,87]. Such phenomena observed in failing ventricular myocytes of different species $[88,89]$ are normalized by ranolazine, which can decrease diastolic $\mathrm{Ca}^{2+}$ accumulation, to prevent the electrophysiological consequences of $\mathrm{Ca}^{2+}$ leak from the SR and finally to avoid the triggering of abnormal spontaneous $\mathrm{Ca}^{2+}$ waves in ventricular myocytes during ischemia or after ATX-II dosing $[21,90,91]$.

\subsection{Antiarrhythmic Mechanisms at the Atrial Level}

In addition to beneficial effects on VA, ranolazine can effectively treat $\mathrm{AF}$, maintaining normal sinus rhythm in AF patients [44,46,92]. Several experimental model studies showed that the drug prevents atrial ectopic beats and $\mathrm{AF}$ initiation. Ranolazine may predominantly delay the atrial rather than the LV AP, accounting for the more significant benefits in AF and lower risk for ventricular side effects $[75,92,93]$. The antiarrhythmic action involves inhibiting different ion currents such as the $\mathrm{I}_{\mathrm{Kr}}$, fast inactivating $\mathrm{I}_{\mathrm{Na}}$, and $\mathrm{I}_{\mathrm{Na} \text {, late, }}$ [55,64]. The consequence is lengthening the atrial AP duration and effective refractory period (ERP) in a use-dependent manner, thus reducing excitability. Of note, ranolazine also inhibits TASK-1, an atrial-specific two-pore domain $\mathrm{K}^{+}(\mathrm{K} 2 \mathrm{P})$ channel upregulated in AF [94].

Ranolazine has a putative atrial-selective action against voltage-gated $\mathrm{Na}^{+}$channels [75], which may account for differences in the biophysical properties of $\mathrm{I}_{\mathrm{Na}}$ as seen between rabbits atrial and ventricular myocytes [95]. Ranolazine potently inhibits $\mathrm{I}_{\mathrm{Na} \text {,peak }}$ in atrial cells, but not in ventricular cardiomyocytes (weak effect) $[75,96,97]$. Indeed, $I_{N a, p e a k}$ current inhibition also depends on the membrane potential and is more significant in depolarized myocytes, such as atrial myocytes. The activation and steady-state inactivation of atrial $\mathrm{I}_{\mathrm{Na}}$ at more negative voltages, together with the higher state-dependent affinity of the drug for inactivated $\mathrm{Na}_{\mathrm{V}}$ channels, may also underly the atrial-selectivity of ranolazine [95]. In addition, chronic AF promotes atrial $\mathrm{I}_{\mathrm{Na}, \text { late }}$ [96], which is likely to reduce the AP firing threshold, initiate depolarization, and increase excitability and atrial arrhythmias turning into AF [98,99]. As in ventricular myocytes, $\mathrm{I}_{\mathrm{Na} \text {,late }}$ can induce DADs [99] through a mechanism involving SR $\mathrm{Ca}^{2+}$ leak and calcium/calmodulin-dependent protein kinase II (CaMKII) activation $[100,101]$.

This mechanism prolongs atrial AP duration in $\mathrm{AF}$ associated with diseases such as congestive HF [100], long QT syndrome [102], or atrial remodeling [103]. Similarly, AF may 
occur in ischemia/reperfusion, after cardiac surgery, and during hypertrophy/HF [104]. Ranolazine prevents the induction of $\beta$-adrenergically-mediated AF and avoids or suppresses persistent AF mediated by vagal stimulation in coronary-perfused canine atria in ischemia/reperfusion conditions [75]. Ranolazine showed similar inhibitory effects on induction or duration of AF initiated by vagal stimulation in intact porcine [105] and canine hearts [106] and a rabbit model of inducible atrial tachyarrhythmia elicited by acetylcholine [107].

Reactive oxygen species (ROS) overproduction and oxidative stress promote AF in multiple pathologies, such as in reperfusion and even during aging, promoting EADs and DADs [108]. Ranolazine normalizes repolarization, suppresses $\mathrm{H}_{2} \mathrm{O}_{2}$-induced EADs and DADs elicited through $\mathrm{I}_{\mathrm{Na} \text {, late }}$ current modulation in isolated atrial guinea pig myocytes $[99,109]$. Ranolazine also terminates induced-atrial flutter and AF in the canine sterile pericarditis model by prolonging the ERP [110]. Similarly, in canine pulmonary vein sleeves, ranolazine causes marked use-dependent inhibition of $\mathrm{Na}^{+}$channel activity, leading to lengthening the ERP, conduction slowing, and blocking and suppressing late phase 3 EADs and DAD-mediated triggered activity [111]. Furthermore, low concentrations of ranolazine or dronedarone produce weak electrophysiological effects and AF suppression when used independently. Conversely, they exert potent synergistic effects when combined, resulting in atrial-selective depression of $\mathrm{Na}^{+}$channel-dependent parameters and effective AF suppression [112]. This work led to a clinical trial showing that in combination, ranolazine (moderate dose) and dronedarone (reduced dose) synergistically reduce AF burden with good tolerance/safety [48]. Similarly, recent experimental work in horses has shown that, compared to single drugs, the combination of dofetilide and ranolazine increased the antiarrhythmic effects on acutely induced $\mathrm{AF}$, affecting cardioversion time, vulnerability at $\mathrm{AF}$, and the duration of $\mathrm{AF}$ [113].

\section{Non-Cardiac Effects of Ranolazine}

\subsection{Neuronal Effects}

Ranolazine targets $\mathrm{Na}_{\mathrm{v}}$ channel persistent activity, i.e., when $\mathrm{Na}_{\mathrm{v}}$ channels fail to inactivate after opening or eventually re-opening [114,115]. Ranolazine can interact with a broad spectrum of $\mathrm{Na}_{\mathrm{v}}$ channel isoforms, including neuronal isoforms, which opens exciting perspectives, yet it may not be ideal for specific clinical purposes [115]. For example, ranolazine can block $\mathrm{I}_{\mathrm{Na} \text {, late }}$ evoked by mutations of $S C N 1 A$, the gene encoding the pore-forming subunit of the $\mathrm{Na}_{\mathrm{v}} 1.1$ channel isoform, frequently involved in altered neuronal excitability associated with a spectrum of genetic epilepsies and a familial form of migraine [116]. Accordingly, neuronal effects of ranolazine have been reported in vivo, opening the possibility for therapeutic applications in the treatment of central neuronal disorders, including inherited forms of epilepsy and a familial form of migraine associated with a persistent $\mathrm{Na}^{+}$current due to slow inactivation or repetitive firing with exaggerated $\mathrm{Na}^{+}$channel opening [116,117].

A clinical trial is underway to test whether ranolazine reduces neuronal hyperexcitability, slows disease progression, and reduces cramp frequency in amyotrophic lateral sclerosis, but the report is currently pending (NCT03472950, University of Kansas Medical Center). The protective mechanism against neuronal ischemia is similar to that reported for riluzole by blocking the $\mathrm{I}_{\mathrm{Na} \text {, late }}$ in several models [118-120]. Another selective $\mathrm{I}_{\mathrm{Na} \text {, late }}$ blocker, GS967, has also displayed potent antiepileptic activity [121]. In addition to inhibition of $\mathrm{I}_{\mathrm{Na} \text {,late }}$ in cardiac cells and antiarrhythmic effects [122,123], GS967 inhibits $\mathrm{I}_{\mathrm{Na} \text {,late }}$ and spontaneous AP firing in pyramidal neurons and prevents both hilar neuron loss and development of mossy fiber sprouting, suppresses seizure activity, and improves survival in genetically epileptic SCN2AQ54 mice [121].

Neuronal effects of ranolazine and other $\mathrm{I}_{\mathrm{Na} \text {,late }}$ blockers open the perspective of an impact on peripheral neurons, excitability, and, indirectly, on the cardiovascular system. The importance of such effects in heart-brain communication may be worth considering for future therapeutic strategies [124]. Ranolazine may normalize the activity of the "neuronal" 
$\mathrm{I}_{\mathrm{Na} \text {,late }}$ responsible for increasing the excitability of dorsal root ganglion neurons (DRG) overexpressing $\mathrm{Na}_{\mathrm{v}} 1.7$ (Figure 2). These neurons are involved in neuropathic pain associated with peripheral nerve excitability $[125,126]$. Ranolazine also improves behavioral signs of neuropathic pain associated with $\mathrm{Na}_{\mathrm{v}} 1.7$ and $\mathrm{Na}_{\mathrm{v}} 1.8$ isoforms [127]. Because $\mathrm{I}_{\mathrm{Na}}$,late currents, especially at or near the threshold for AP firing, can increase excitability, drugs that selectively target these currents in nociceptive neurons could be useful in treating pain [115]. In neurons, as in cardiac cells, the effect of ranolazine is state-dependent, as shown for $\mathrm{Na}_{\mathrm{v}} 1.1, \mathrm{Na}_{\mathrm{v}} 1.2$, and $\mathrm{Na}_{\mathrm{v}} 1.7[117,128]$. Ranolazine may interact with the $\mathrm{Na}_{\mathrm{v}}$ channels inactivated states, reducing excitability and epileptiform activity in neuronal cultures $[116,117,125,128]$.

$200 \mathrm{pA}$
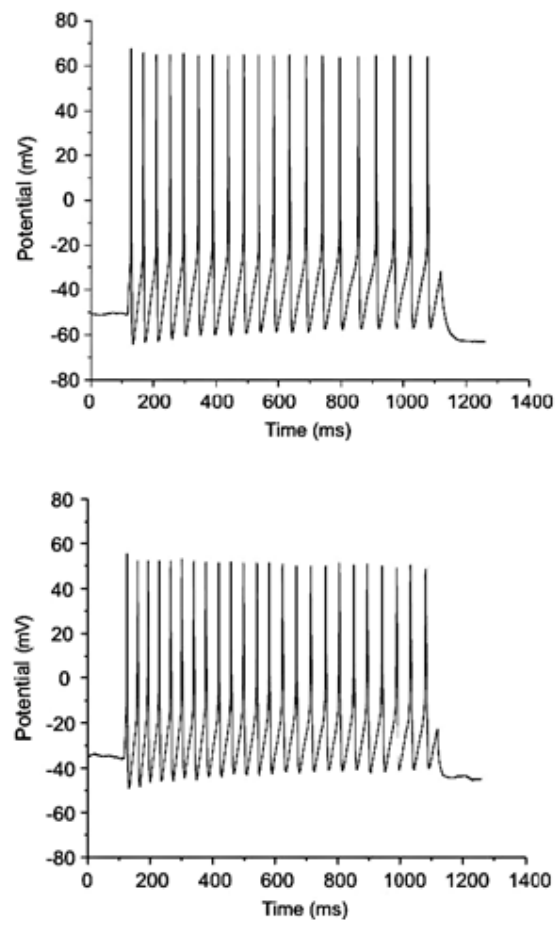

$400 \mathrm{pA}$
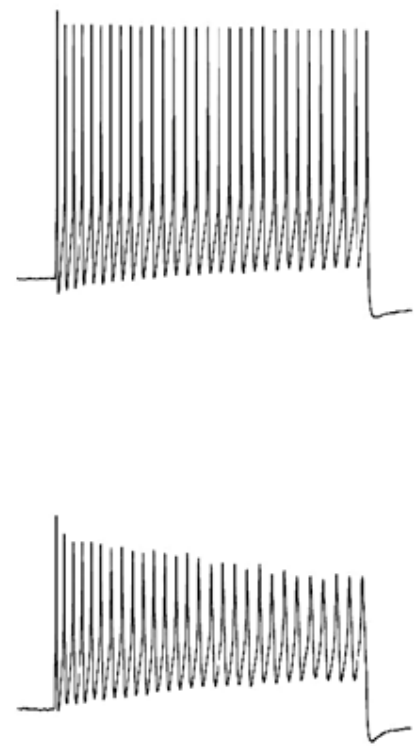

$600 \mathrm{pA}$

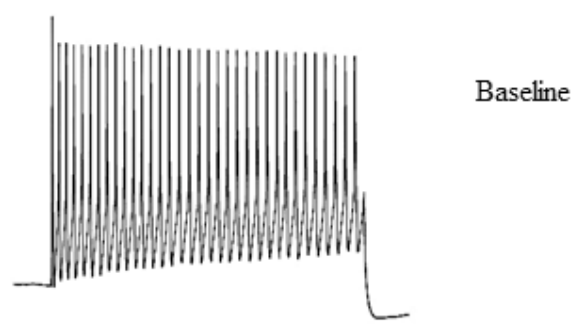

$10 \mu \mathrm{M}$ Ranolazine

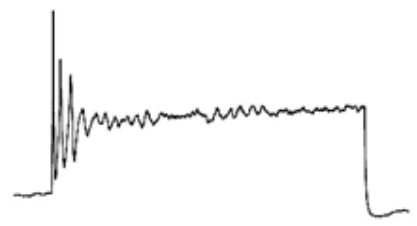

Figure 2. Clinically relevant concentration of ranolazine blocks high-frequency firing of Dorsal Root Ganglion (DRG) neurons expressing the wild-type (WT) Nav1.7 isoform. Traces illustrating the response (high-frequency firing phenotype) to 1-s duration current injections of $200 \mathrm{pA}, 400 \mathrm{pA}$, and $600 \mathrm{pA}$ both before (upper row) and after (lower row) exposure to $10 \mu \mathrm{M}$ ranolazine in DRG neuron transfected with human $\mathrm{Na}_{\mathrm{v}}$ 1.7-WT channels. Reproduced from Figure 6B [125], an open-access article distributed under the terms of the Creative Commons CC-BY 2.0 Attribution license.

The neuronal isoforms $\mathrm{Na}_{\mathrm{v}} 1.1$ and $\mathrm{Na}_{\mathrm{v}} 1.6$ increase proportionally with $\mathrm{I}_{\mathrm{Na} \text {,late }}$ in pressure-overloaded rat hearts [129-131]. Of significant interest, ranolazine preserved or improved LV ejection fraction during a 24 month follow-up period when added to guideline-driven therapy in congestive HF $[30,132]$. The high sympathovagal balance was improved, which directly affected autonomic $\mathrm{Na}^{+}$channels. In line with clinical data, ranolazine delivered intraperitoneally in rats with chronic HF alleviated sympathetic nerve activity and improved the impaired LV function, amplified following vagal activation [133]. Consistently, ranolazine attenuated the heightened norepinephrine and B-type natriuretic peptide- 45 and improved cardiac function in rats with chronic ischemic HF [134]. In addition to electrophysiological actions, neuroprotection and cardioprotection may involve anti-inflammatory and antioxidant effects [135-139]. Future studies with ranolazine may consider these benefits due to the recent success of non-specific anti-inflammatory molecules after myocardial infarction [140]. 


\subsection{Vascular Effects of Ranolazine}

The primary mechanism of ranolazine antianginal benefits was first established and emphasized as cardiac protection against the metabolic consequences of ischemia. This mechanism contrasts markedly with other classical antianginal drugs that directly affect coronary flow. However, there is now strong experimental and clinical evidence of ranolazine vascular effects, which may contribute to its beneficial effects in patients with stable angina [141]. Indeed, ranolazine induces dose-dependent relaxation of arterial rings from healthy (Figure 3A) and diabetic rats, previously contracted with phenylephrine [141-143], and substantially improves the regional coronary blood flow in areas of myocardial ischemia [144]. At therapeutic doses, ranolazine also exerts an additive vasorelaxant effect in rabbit aortic rings when combined with nicardipine [145]. Although other reports challenge this effect [143], studies confirmed that ranolazine could improve angina and myocardial perfusion in patients with severe coronary microvascular dysfunction [146-148]. Specifically, the synthesis/release of nitric oxide by the endothelium might also contribute, yet the ranolazine vasodilatory effect is predominantly endotheliumindependent $[141,142,149,150]$. Ranolazine inhibits $\mathrm{Na}_{\mathrm{V}}$ channels and antagonizes $\alpha_{1}$ adrenergic receptors in vascular smooth muscle cells (VSMCs), in line with its pleiotropic effects $[142,151]$. Blockade of $\alpha_{1}$-adrenergic receptors may also account for vasodilatory effect after intracoronary or intra-femoral bolus injection in anesthetized pigs [152]. Experiments in rat intrarenal arteries reached similar conclusions [153]. Ranolazine could also improve vasodilatation through relaxant and antiadrenergic effects in the human saphenous vein [154]. Several groups recently reported potential interest in ranolazine in pulmonary arterial hypertension by reducing cardiovascular death in an experimental rat model. Thus, ranolazine may improve pulmonary hemodynamics, alleviate cardiac remodeling (right ventricle) and improve susceptibility to ventricular arrhythmia [155,156]. Ranolazine was also reported as a safe treatment in preliminary works on pulmonary arterial hypertension $[157,158]$, which was confirmed recently in a clinical trial $[159,160]$.

A
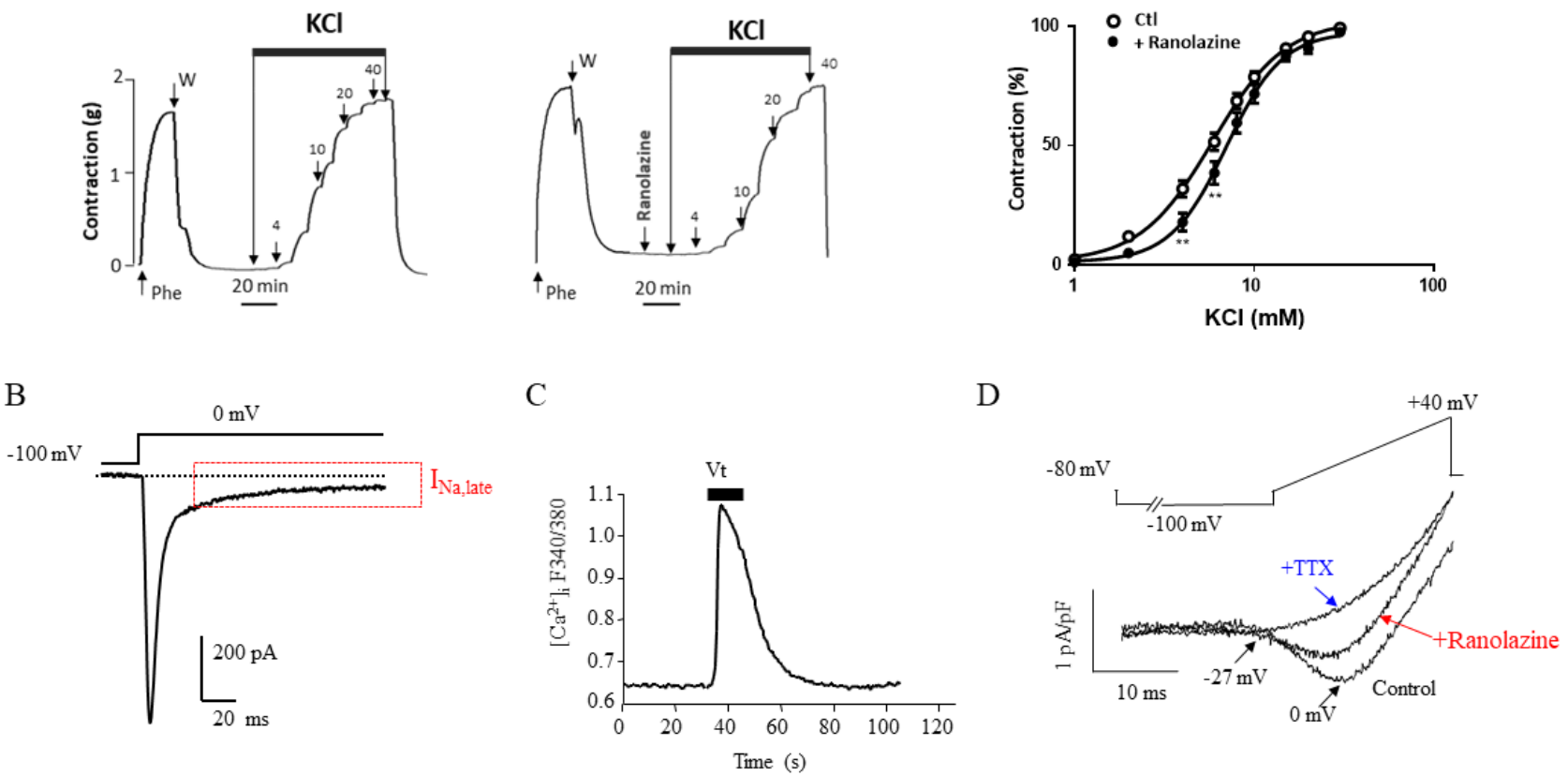

Figure 3. Voltage-gated $\mathrm{Na}^{+}$currents in arteries and effect of ranolazine. Effect of the addition of cumulative doses of $\mathrm{KCl}(1$ to $40 \mathrm{mM})$ on a $\mathrm{Na}_{\mathrm{v}}$ channel-dependent component of contraction recorded in the absence (left) and the presence of ranolazine $(20 \mu \mathrm{M})($ right $)$ in rat aortic rings. Graphs summarize the dose-response curves obtained for $\mathrm{KCl}$. Averaged data expressed as percentage of the maximal contraction induced by $\mathrm{KCl}(n=15)(\mathbf{A})$. Reproduced from Figure 3B in [142]. (B) Typical 
$\mathrm{Na}^{+}$current with an $\mathrm{I}_{\mathrm{Na} \text {,late }}$ evoked at a test potential of $0 \mathrm{mV}$ from a holding potential of $-100 \mathrm{mV}$, using the whole-cell patch-clamp technique, in a primary cultured human coronary myocyte (HCM) (unpublished personal data). The experiment was performed as described [161]. (C) Increasing effect of the $\mathrm{Na}^{+}$channel agonist veratridine $(\mathrm{Vt} ; 10 \mu \mathrm{M})$ on intracellular $\mathrm{Ca}^{2+}\left(\left[\mathrm{Ca}^{2+}\right]_{i}\right)$ in a fura-2loaded HCM (unpublished personal data). The experiment was performed as described in [162]. (D) Antagonist effect of ranolazine $(20 \mu \mathrm{M})$ on a veratridine-induced $\mathrm{I}_{\mathrm{Na}}$ in a primary cultured rat aortic myocyte. The $\mathrm{I}_{\mathrm{Na}}$ current was evoked by a $40 \mathrm{~ms}$ ramp from $-80 \mathrm{mV}$ to $+40 \mathrm{mV}$, following a 2-sec prepulse at $-100 \mathrm{mV}$, from a holding potential of $-80 \mathrm{mV}$ in the presence of $\mathrm{Vt}(100 \mu \mathrm{M})$. Tetrodotoxin (TTX; $1 \mu \mathrm{M}$ ) was added after ranolazine to block all $\mathrm{I}_{\mathrm{Na}}$ current. Arrows indicate the current's activation and maximal amplitude with the corresponding voltages. Reproduced from Figure $1 \mathrm{~A}$ in [142].

Suggesting vascular channel inhibition by ranolazine was provocative and somehow unexpected because its antianginal benefits were primarily attributed to its effects on car-

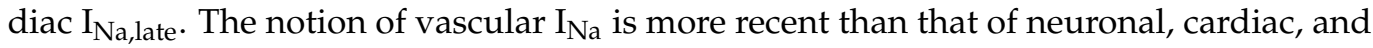
muscular $\mathrm{I}_{\mathrm{Na}}$ present in excitable cells [163]. Vascular $\mathrm{I}_{\mathrm{Na}}$ currents have been identified in rabbit and human pulmonary arteries and various primary VSMCs from the arterial smooth muscle layer (rat, pig, and human) [161,164-168]. Notably, we found an atypical $\mathrm{I}_{\mathrm{Na}}$ in primary cultured human coronary and aortic myocytes (Figure $3 \mathrm{~B}$ ). This $\mathrm{I}_{\mathrm{Na}}$ is activated at more positive potentials than most $\mathrm{I}_{\mathrm{Na}}$ subtypes and exhibits a large late component that is related to inactivation failure and is observed even for large depolarizations $(>0 \mathrm{mV})[161,162,166]$. This current causes a basal $\mathrm{Na}^{+}$influx into myocytes that regulates both intracellular sodium $\left(\left[\mathrm{Na}^{+}\right]_{\mathrm{i}}\right)$ and $\mathrm{Ca}^{2+}\left(\left[\mathrm{Ca}^{2+}\right]_{\mathrm{i}}\right)$ via activation of depolarization-gated $\mathrm{Ca}^{2+}$ channels and NCX [162]. The beneficial effects observed by ranolazine, mentioned above, may result from an inhibition of the pulmonary vascular $\mathrm{I}_{\mathrm{Na} \text {,late }}$ to explain its effect in pulmonary hypertension [169], in line with the presence and blockade of TTX-sensitive $\mathrm{Na}_{\mathrm{V}}$ channel isoforms in human pulmonary artery VSMCs $[168,170]$. Veratridine induces $\mathrm{Na}_{\mathrm{v}}$ channel-dependent increases in intracellular $\mathrm{Ca}^{2+}$ primary cultured human coronary myocytes (Figure $3 \mathrm{C}$ ), and the $\mathrm{I}_{\mathrm{Na}}$ promoted by veratridine can be blocked by ranolazine in rat primary cultured aortic VSMCs (Figure 3D). These effects could contribute to the benefits of ranolazine in patients with stable ischemic heart disease compared with traditional antianginals, such as beta-blockers, $\mathrm{Ca}^{2+}$ channel blockers, or long-acting nitrate [171].

\subsection{Gluco-Metabolic Effects of Ranolazine}

A promising therapeutic approach for ischemic heart disease and HF is metabolic modulation to optimize energy substrate utilization [172]. Ranolazine may preserve the LV ejection fraction and decrease high sympathovagal balance when added to guideline-driven therapy in chronic HF [132]. Several animal studies and at least three double-blinded, randomized, placebo-controlled clinical trials have brought data in favor of a beneficial effect of ranolazine as a metabolic modulator [173]. Ranolazine is efficient in short-term or intermittent ischemia conditions and during stress challenge or exercise but presents no beneficial effect in "no-flow ischemia" situations [173]. Ranolazine stimulates glucose oxidation and partially reduces fatty acid oxidation, leading to improved ATP production $/ \mathrm{O}_{2}$ consumption ratio, and diminished $\mathrm{H}^{+}$, lactate, and harmful fatty acyl intermediates [174]. Ranolazine may promote the utilization of substrates to produce enough energy to improve contractile performance. In an isolated rabbit heart model, ranolazine consistently limited the decrease in cardiac ATP during ischemia in a concentration-dependent manner, allowing a significant cardio-protective effect during ischemia and reperfusion [175].

Recent studies have re-emphasized that ranolazine exerts a well-tolerated glucometabolic effect and positive glucose control in patients with diabetes [4,32,173]. In particular, a metaanalysis showed improved glycated hemoglobin (HbA1c) without increased risk of hypoglycemia, thus benefiting patients with type 2 diabetes and chronic stable angina [176-178]. Ranolazine was also proposed as first-line therapy in diabetes and coronary artery disease $[179,180]$. Thus, ranolazine may complement or supplant traditional drugs, especially those with potentially harmful hemodynamic effects [178]. Interestingly, during exercise, 
patients receiving ranolazine generate more cardiac work than those receiving placebo. Unlike atenolol, ranolazine's antianginal and anti-ischemic effects did not depend on decreased cardiac work affected by reductions in heart rate, blood pressure, or rate-pressure product [181]. Moreover, patients treated with ranolazine can exercise for a longer time before the appearance of angina symptoms and myocardial ischemia (ST-segment depression) $[182,183]$.

\subsection{Skeletal Muscle Effects of Ranolazine}

Patients with myotonia congenita present muscle hyperexcitability due to loss-offunction mutations in the $\mathrm{ClC}-1$ chloride channel in skeletal muscle. These mutations cause involuntary firing of muscle action potentials (myotonia), producing muscle stiffness due to slow afterdepolarization. The individuals experience spells of muscle stiffness or when the muscles do not relax after contracting. The mechanism involved a late $\mathrm{Na}^{+}$ current triggering spontaneous myotonic AP. Patch-clamp studies on muscle from a mouse model of myotonia congenita allowed to conclude that the ideal myotonia therapy would selectively block a sustained $\mathrm{Na}^{+}$current induced by loss-of-function mutations in the ClC-1 chloride channel and spare the transient $\mathrm{Na}^{+}$current $[184,185]$. Ranolazine was thus shown efficient in this pathology [184]. Another group obtained similar results and noted that ranolazine produced fewer side effects and was as effective as mexiletine at a dose that had none of the mexiletine's hypoexcitability side effects [186]. Following these observations, a pilot study on thirteen participants established that ranolazine could improve signs and symptoms of myotonia and muscle stiffness in patients with myotonia congenita. In this study, ranolazine appeared to be well tolerated over four weeks and improved signs and symptoms of muscle stiffness. The findings of this study suggested investigating ranolazine's effect in a more extensive controlled study $[187,188]$. Similarly, a study indicated that a block of human Nav 1.4 is helpful to reduce the sustained AP firing in paramyotonia congenita [189]. This work paved the way for a single-center trial of ranolazine to evaluate efficacy and tolerability in patients with paramyotonia congenita. In this study, the subjective symptoms of stiffness, weakness, and pain, as well as clinical and electrical myotonia, were evaluated. This study supported the use of ranolazine as a treatment for myotonia in paramyotonia congenita and suggested that a randomized, placebo-controlled trial is warranted [187].

\subsection{Ranolazine and Cancer}

The capacity to metastasize is one of the hallmarks of cancer, and usually, death due to cancer is not caused by the primary tumor but rather by the metastatic spread. The lack of effective therapy for preventing metastasis results in a high mortality rate in oncology. Reducing the risk of metastasis may significantly improve survival and quality of life [190]. Old drugs and compounds have shown anti-metastasis activity by acting on the invasive capacity of these cells [190]. Cancer cells expressed functional voltage-gated Na channels playing a significant role in disease progression in the prostate, breast, lung cancers, and leukemia [191]. Thus, the expression of $\mathrm{Na}_{\mathrm{v}}$ channels in tumor cells questions their role in cancer therapy and opens perspectives for a potential new target in oncology [191-193]. Indeed, $\mathrm{Na}_{\mathrm{v}} 1.7, \mathrm{Na}_{\mathrm{v}} 1.6$, and $\mathrm{Na}_{\mathrm{v}} 1.5$ 's functional expression are associated with invasive properties of some cancer cell lines [191]. In cancer cells, $\mathrm{Na}_{\mathrm{v}}$ channels are not involved in AP genesis as in excitable cells and instead serve to regulate resting $\mathrm{Ca}^{2+}$ homeostasis, essential proteases release, and $\mathrm{pH}$ regulation through $\mathrm{Na}^{+}-\mathrm{H}^{+}$exchanger, two phenomena important to cancer invasiveness. In addition, cancer cell lines that express $\mathrm{Na}_{\mathrm{v}}$ are more metastatic and correlate with patient mortality [194]. Thus, channel blockers were tested in cancer, particularly blockers of $\mathrm{I}_{\mathrm{Na} \text {,late }}[195,196]$ such as ranolazine assessed on breast cancer cell invasiveness and lung colonization [197]. In vitro, ranolazine inhibits $\mathrm{Na}_{\mathrm{v}}$ currents and reduces invasiveness in breast cancer cells. In vivo, the injection of ranolazine significantly reduced lung colonization by human breast cancer cells in immunodepressed mice with no apparent toxic effect. Similar results were recently obtained in a rat model of prostate 
cancer [198]. In addition to its electrophysiologic effects, the metabolic modulatory effect of ranolazine was also tested in cancer. Targeting fat oxidation in mouse prostate cancer decreases tumor growth and stimulates anti-cancer immunity [199]. By contrast, by favoring ATP production, Suckow et al. observed that ranolazine caused a dose-dependent increase in tumor number in APC(Min/+) mice, a model of spontaneous intestinal tumorigenesis [200]. Furthermore, in an in vitro study of colorectal cancer invasiveness, ranolazine increased invasiveness under hypoxia, whereas its effect was lower under normoxia [201]. To our knowledge, the efficacy and safety of ranolazine or other $\mathrm{Na}_{\mathrm{v}}$ channel blockers in oncology have not been assessed in clinical trials. However, ranolazine may reduce the cardiotoxicity of anticancer therapy (trastuzumab, doxorubicin) in mice, thus paving the way to a clinical trial [138,202-204]. A controlled trial is needed regarding the potential of ranolazine on relieving chemotherapy-related diastolic dysfunction and its safety profile in cancer patients compared to that of the general population [204].

\section{Adverse Effects of Ranolazine}

Numerous trials assessed ranolazine tolerability and safety. Ranolazine is beneficial in angina as monotherapy (MARISA study) and in combination with other suboptimal antianginal agents (CARISA, RAN080). Long-term therapy seems well-tolerated without significant clinically hemodynamic effects in patients with chronic angina [20]. However, clinical studies have reported adverse reactions [205]. Overall, 6\% of patients discontinued treatment due to an adverse event (vs. 3\% in the placebo groups), mainly dizziness, headache, nausea, debility, and constipation (https: / / www.ncbi.nlm.nih.gov / books /NBK507828/ accessed on: 10 December 2021). Syncope, confusion, tinnitus, vertigo, blurred vision, dyspnea, hematuria, bradycardia, palpitations, hypotension, orthostatic hypotension, thrombocytopenia, leukopenia, abdominal pain, dry mouth, vomiting, anorexia, dyspepsia, peripheral edema, angioedema, renal failure, eosinophilia, paresthesia, tremor, pulmonary fibrosis, and excessive sweating have also been reported. For example, during the first two years of the Ranolazine Open Label Experience (ROLE) study, the occurrence of an adverse effect was the most common reason for treatment discontinuation in $10 \%$ of patients [28]. In this study, adverse events were mainly general (dizziness) and digestive (constipation) and concerned nearly $12 \%$ of patients enrolled in the study [28]. In the MERLIN TIMI randomized trial ( $n=6560$ patients included within $48 \mathrm{~h}$ of an acute coronary syndrome), the ranolazine tolerance profile was favorable in patients with prior angina [29]. The most common adverse effects were similar to those recorded in the ROLE study: dizziness (12\%), nausea $(10 \%)$, and constipation (9\%) [29]. Overall, ranolazine was discontinued due to an adverse event by $8 \%$ of patients [29]. The reported side effects were not specific as they are shared by other Class I [206] and some Class III anti-arrhythmic drugs [207,208].

Ranolazine side effects are strongly related to the administered dose and the presence of hepatic and/or renal impairment. For example, in the MERLIN TIMI trial, ranolazine dose (1000 mg twice per day per os) was decreased in $11 \%$ of patients due to renal dysfunction, in $0.6 \%$ of patients due to persistent prolongation of the corrected QT interval, and in $8.6 \%$ of patients due to other adverse events [29]. In the MARISA trial (500 mg, $1000 \mathrm{mg}$, and $1500 \mathrm{mg}$ twice per day), study interruption for adverse events was more frequent in the $1500 \mathrm{mg}$ group [20]. Another study described the first case of neurologic adverse events in an 81-year-old woman with coronary artery disease, renal impairment, and mild neurologic disease who received ranolazine for symptomatic control of a non-ST-segment elevation myocardial infarction [209]. The patient started with $500 \mathrm{mg}$ twice per day at admission, and on day 3 , the dose was increased to $1000 \mathrm{mg}$ twice per day. Just $48 \mathrm{~h}$ after the dose increase, she experienced dysarthria, dysmetria, hallucinations, worsening of tremors, and difficulty in word-finding, probably due to the combined effect of the dose increase and favoring factors, like advanced age, renal impairment, and baseline mild neurologic disease.

However, recent work highlighted that neurological complication, including seizures, is rare after the initiation of ranolazine [210]. Since delirium was noted as a possible rare side 
effect [211], case reports could provide additional information to determine the optimal regimen for elderly patients and individuals with renal impairment [209]. Indeed, ranolazine inhibits the tubular secretion of creatinine but does not affect the glomerular filtration rate (https: / / www.ncbi.nlm.nih.gov/books/NBK507828/ accessed on 10 December 2021). However, acute renal failure has been reported in patients with severe renal impairment (creatinine clearance lower than $30 \mathrm{~mL}$ per $\mathrm{min}$ ). Ranolazine should be discontinued in patients with renal failure, and it is contraindicated in patients with creatinine clearance lower than $30 \mathrm{~mL}$ per min (e.g., patients on dialysis) and in cirrhotic patients (https: / / www.ncbi.nlm.nih.gov/books/NBK507828/ accessed on 10 December 2021). Considering renal failure or hepatic impairment, two Phase I, randomized, open-label studies, have been conducted to assess the effect of ranolazine pharmacokinetics in patients with poor hepatic and poor renal function [212]. The two studies revealed that the concentration of ranolazine increases by about $50 \%$ in patients with mild, moderate, and severe renal impairment and by about $75 \%$ in patients with moderate hepatic impairment. In healthy patients, slightly elevated blood urea nitrogen (BUN) and serum creatinine levels were reported without renal toxicity and are considered reversible [213].

Ranolazine is metabolized in the liver by CYP3A4 and CYP2D6. Thus, co-administration of their inhibitors (ketoconazole, macrolides, clarithromycin, ritonavir), diltiazem, fluconazole, erythromycin, and verapamil (CYP3A4) can affect ranolazine's clearance to increase plasma level (up to three times). Therefore, it is contraindicated unless the dose is adjusted [214], as in combination with tricyclic antidepressants and some antipsychotics [215]. Numerous immunosuppressants, like sirolimus, are also a substrate for CYP3A4. Drug interaction with ranolazine has been considered to avoid a toxic accumulation of the drugs (notably in kidney transplant patients) [216]. Hepatic impairment may also increase plasma concentrations and QT lengthening via $\mathrm{I}_{\mathrm{Kr}}$ inhibition. Administration of ranolazine in patients with a family history of long QT syndrome or with known prolonged QT interval should be carefully considered. Patients initiated on ranolazine should undergo a baseline ECG with follow-up monitoring of QT interval.

A dose-related interaction between ranolazine and metformin, two drugs frequently co-administered in subjects with chronic angina and co-morbid type 2 diabetes mellitus, was also observed [217]. Ranolazine may also increase serum digoxin levels by 1.5 times, leading to reducing digoxin dosage in patients who are taking both drugs [3]. Ranolazine can also increase simvastatin Cmax approximately two-fold [218].

In contrast, trials testing ranolazine combined with amiodarone/dronedarone [47-49] or even ivabradine [50] showed good tolerance and safety. Similarly, twice-daily doses of ranolazine increased exercise capacity and provided additional antianginal relief to symptomatic patients with severe chronic angina under standard doses of atenolol, amlodipine, or diltiazem with no evidence for adverse consequences during 1 to 2 years of therapy [17].

\section{Conclusions}

Ranolazine has multiple molecular targets on cardiac cells and pleiotropic biological actions with novel challenging findings that it also affects vessels, neurons (Figure 4), and other organs and parameters (e.g., gluco-metabolism, skeletal muscles). These properties may be fascinating in preventing adverse cardiovascular outcomes by acting on metabolism, glycemia, vasculature, autonomic nervous system, and $\mathrm{Na}^{+}$transports. All these systems or functions are rarely altered independently of each other and form a continuum of the pathologic progression leading to fatal events. This is the case in ischemic and chronic heart diseases of different etiologies related to diabetes, obesity, or heart failure. Acting on several parameters with one compound able to work on numerous interrelated "functions" could be desirable, and the notion of a dirty drug should be re-evaluated since ranolazine seems well tolerated in patients. In addition to its antianginal clinical indications, a large amount of scientific evidence in the literature and clinical observations call for a repositioning of this drug as an antiarrhythmic, in pulmonary arterial hypertension, in myotonia, or even in diabetes, even if the link between the different molecular effects of ranolazine and the 
empirically observed benefits is complex and most often unclear. More precise pharmacological approaches and an integrative vision of the multiple effects of this molecule (like others) could open up new perspectives for its clinical use, particularly in the context of declining or leveling off the results of R\&D programs. Thus, this strategy could take advantage of the untapped potential of older drugs that are sometimes poorly studied or on a variable too specific for a more complex problem. The combined use of ancient molecules, such as ranolazine, could help gain efficiency or target new indications while reducing the side effects. This can be achieved, for example, by varying the doses administered as for dronedarone/amiodarone or dofetilide for arrhythmia.

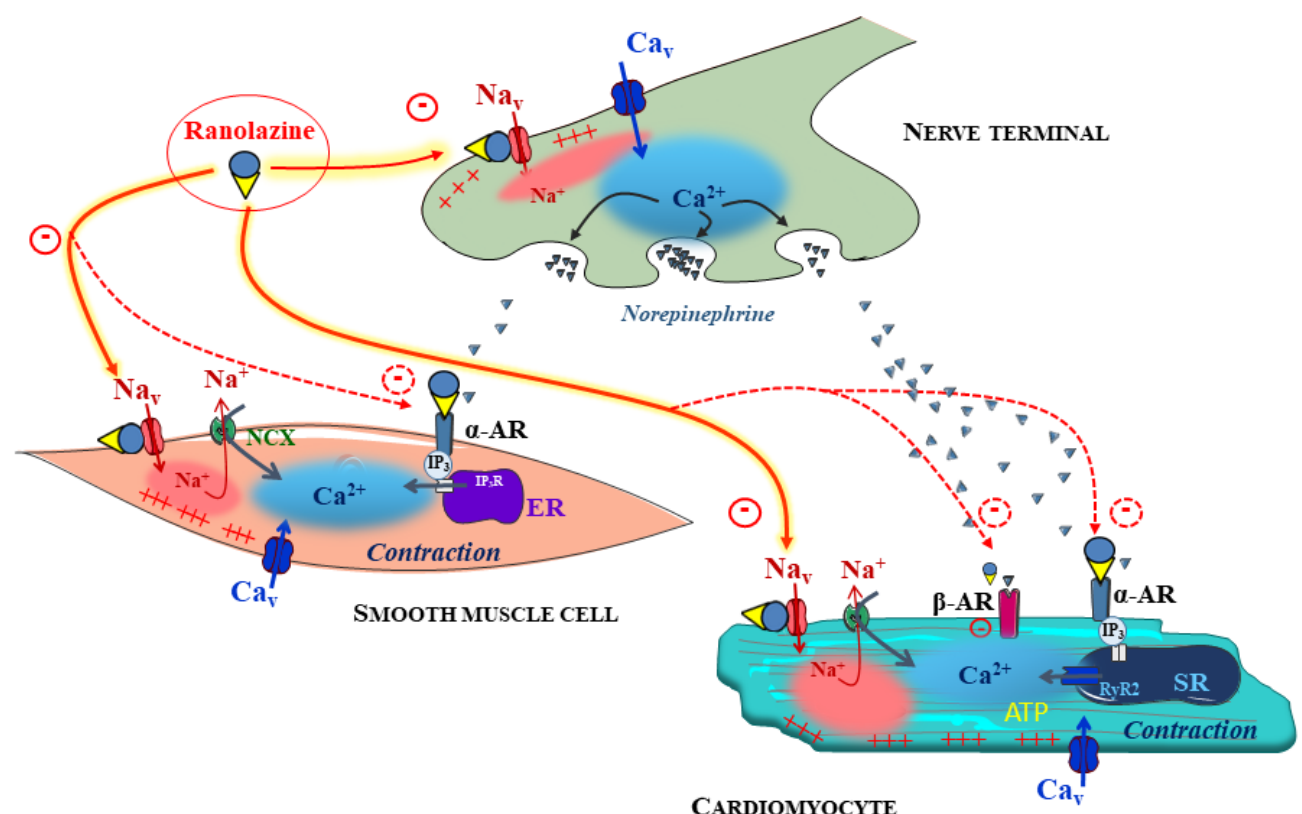

Figure 4. Integrated vision of ranolazine's putative direct and indirect effects on the cardiovascular system. The therapeutic benefits of ranolazine in the treatment of ischemia and angina pectoris have been documented as primarily based on the inhibition of $\mathrm{I}_{\mathrm{Na} \text {,late }}$ in heart cells. However, there is mounting evidence that ranolazine also interacts with a broad spectrum of $\mathrm{Na}_{\mathrm{v}}$ channels, including cardiac and neuronal isoforms. Reports from the literature point to similar mechanisms in vascular smooth muscle cells and neurons, opening the possibility that these effects may contribute to the overall anti-ischemic effect of ranolazine. Combined $\alpha_{1}$-adrenergic receptor antagonization and inhibition of the $\mathrm{Na}_{\mathrm{v}}$ channels of vascular smooth muscle cells may account for vascular effects of ranolazine. At the sympathetic perivascular nerve endings, ranolazine may potentially reduce electrical activity and inhibit the release of norepinephrine, in addition to the inhibition of $\alpha_{1}$ adrenergic receptors, which may also be relevant for the antianginal effects of the drug. The inhibition of cardiac release of norepinephrine may also have favorable effects by reducing cardiac adrenergic stimulation and improving ATP consumption. These complementary effects have to be confirmed from molecular targets to integrative models.

Supplementary Materials: The following are available online at https: / www.mdpi.com/article/ 10.3390/ph15010031/s1, Table S1: Summary of main experimental studies of ranolazine; Table S2: Summary of main clinical studies of ranolazine.

Author Contributions: Conceptualization, S.R. (Sylvain Richard), J.T.; writing-original draft preparation, J.T., S.R. (Sylvain Richard), A.V., N.F., S.R. (Sarah Rouhana); writing-review and editing, J.T., S.R. (Sylvain Richard), supervision, S.R. (Sylvain Richard), J.T.; funding acquisition, S.R. (Sarah Rouhana), N.F., J.T. All authors have read and agreed to the published version of the manuscript.

Funding: This work was supported by the Bilateral Research Collaborative program between France and Lebanon (PHC CEDRE 2015, N 32955NG to SRo, SRi, and NF), the Research Council of Saint Joseph University of Beirut (travel, SRo), the Fondation de France (N²013-00038586 to SRi and JT), the Association Française contre les Myopathies ( $\mathrm{N}^{\circ}$ 23273-2020 to SRi). 
Institutional Review Board Statement: Not applicable.

Informed Consent Statement: Not applicable.

Data Availability Statement: Not applicable.

Conflicts of Interest: The authors declare no conflict of interest.

\section{References}

1. Balla, C.; Pavasini, R.; Ferrari, R. Treatment of Angina: Where Are We? Cardiology 2018, 140, 52-67. [CrossRef]

2. Hale, S.L.; Shryock, J.C.; Belardinelli, L.; Sweeney, M.; Kloner, R.A. Late Sodium Current Inhibition as a New Cardioprotective Approach. J. Mol. Cell. Cardiol. 2008, 44, 954-967. [CrossRef]

3. Nash, D.T.; Nash, S.D. Ranolazine for Chronic Stable Angina. Lancet Lond. Engl. 2008, 372, 1335-1341. [CrossRef]

4. Rayner-Hartley, E.; Sedlak, T. Ranolazine: A Contemporary Review. J. Am. Heart Assoc. 2016, 5, e003196. [CrossRef]

5. Anderson, J.R.; Nawarskas, J.J. Ranolazine: A Metabolic Modulator for the Treatment of Chronic Stable Angina. Cardiol. Rev. 2005, 13, 202-210. [CrossRef]

6. Grynberg, A. Effectors of Fatty Acid Oxidation Reduction: Promising New Anti-Ischaemic Agents. Curr. Pharm. Des. 2005, 11, 489-509. [CrossRef]

7. Schofield, R.S.; Hill, J.A. Role of Metabolically Active Drugs in the Management of Ischemic Heart Disease. Am. J. Cardiovasc. Drugs Drugs Devices Interv. 2001, 1, 23-35. [CrossRef]

8. Anderson, S.E.; Murphy, E.; Steenbergen, C.; London, R.E.; Cala, P.M. Na-H Exchange in Myocardium: Effects of Hypoxia and Acidification on Na and Ca. Am. J. Physiol. 1990, 259, C940-C948. [CrossRef]

9. Imahashi, K.; Pott, C.; Goldhaber, J.I.; Steenbergen, C.; Philipson, K.D.; Murphy, E. Cardiac-Specific Ablation of the Na ${ }^{+}-\mathrm{Ca}^{2+}$ Exchanger Confers Protection against Ischemia/Reperfusion Injury. Circ. Res. 2005, 97, 916-921. [CrossRef]

10. Steenbergen, C.; Perlman, M.E.; London, R.E.; Murphy, E. Mechanism of Preconditioning. Ionic Alterations. Circ. Res. 1993, 72, 112-125. [CrossRef]

11. Thireau, J.; Pasquié, J.-L.; Martel, E.; Le Guennec, J.-Y.; Richard, S. New Drugs vs. Old Concepts: A Fresh Look at Antiarrhythmics. Pharmacol. Ther. 2011, 132, 125-145. [CrossRef]

12. Bing, O.H.; Keefe, J.F.; Wolk, M.J.; Finkelstein, L.J.; Levine, H.J. Tension Prolongation during Recovery from Myocardial Hypoxia. J. Clin. Investig. 1971, 50, 660-666. [CrossRef]

13. Goodwill, A.G.; Dick, G.M.; Kiel, A.M.; Tune, J.D. Regulation of Coronary Blood Flow. Compr. Physiol. 2017, 7, 321-382. [CrossRef]

14. Ju, Y.K.; Saint, D.A.; Gage, P.W. Hypoxia Increases Persistent Sodium Current in Rat Ventricular Myocytes. J. Physiol. 1996, 497 Pt 2, 337-347. [CrossRef]

15. Shander, G.S.; Undrovinas, A.I.; Makielski, J.C. Rapid Onset of Lysophosphatidylcholine-Induced Modification of Whole Cell Cardiac Sodium Current Kinetics. J. Mol. Cell. Cardiol. 1996, 28, 743-753. [CrossRef]

16. Undrovinas, A.I.; Maltsev, V.A.; Sabbah, H.N. Repolarization Abnormalities in Cardiomyocytes of Dogs with Chronic Heart Failure: Role of Sustained Inward Current. Cell. Mol. Life Sci. 1999, 55, 494-505. [CrossRef]

17. Chaitman, B.R.; Pepine, C.J.; Parker, J.O.; Skopal, J.; Chumakova, G.; Kuch, J.; Wang, W.; Skettino, S.L.; Wolff, A.A. Combination Assessment of Ranolazine In Stable Angina (CARISA) Investigators Effects of Ranolazine with Atenolol, Amlodipine, or Diltiazem on Exercise Tolerance and Angina Frequency in Patients with Severe Chronic Angina: A Randomized Controlled Trial. JAMA 2004, 291, 309-316. [CrossRef] [PubMed]

18. Antzelevitch, C.; Belardinelli, L.; Zygmunt, A.C.; Burashnikov, A.; Di Diego, J.M.; Fish, J.M.; Cordeiro, J.M.; Thomas, G. Electrophysiological Effects of Ranolazine, a Novel Antianginal Agent with Antiarrhythmic Properties. Circulation 2004, 110, 904-910. [CrossRef]

19. Tavazzi, L. Ranolazine, a New Antianginal Drug. Future Cardiol. 2005, 1, 447-455. [CrossRef]

20. Chaitman, B.R.; Skettino, S.L.; Parker, J.O.; Hanley, P.; Meluzin, J.; Kuch, J.; Pepine, C.J.; Wang, W.; Nelson, J.J.; Hebert, D.A.; et al. Anti-Ischemic Effects and Long-Term Survival during Ranolazine Monotherapy in Patients with Chronic Severe Angina. J. Am. Coll. Cardiol. 2004, 43, 1375-1382. [CrossRef]

21. Fraser, H.; Belardinelli, L.; Wang, L.; Light, P.E.; McVeigh, J.J.; Clanachan, A.S. Ranolazine Decreases Diastolic Calcium Accumulation Caused by ATX-II or Ischemia in Rat Hearts. J. Mol. Cell. Cardiol. 2006, 41, 1031-1038. [CrossRef]

22. Yu, S.; Li, G.; Huang, C.L.-H.; Lei, M.; Wu, L. Late Sodium Current Associated Cardiac Electrophysiological and Mechanical Dysfunction. Pflugers Arch. 2018, 470, 461-469. [CrossRef]

23. Antzelevitch, C.; Burashnikov, A.; Sicouri, S.; Belardinelli, L. Electrophysiologic Basis for the Antiarrhythmic Actions of Ranolazine. Heart Rhythm 2011, 8, 1281-1290. [CrossRef] [PubMed]

24. Allen, T.J.; Chapman, R.A. Effects of Ranolazine on L-Type Calcium Channel Currents in Guinea-Pig Single Ventricular Myocytes. Br. J. Pharmacol. 1996, 118, 249-254. [CrossRef]

25. Liu, Z.; Williams, R.B.; Rosen, B.D. The Potential Contribution of Ranolazine to Torsade de Pointe. J. Cardiovasc. Dis. Res. 2013, 4 , 187-190. [CrossRef]

26. Schram, G.; Zhang, L.; Derakhchan, K.; Ehrlich, J.R.; Belardinelli, L.; Nattel, S. Ranolazine: Ion-Channel-Blocking Actions and in Vivo Electrophysiological Effects. Br. J. Pharmacol. 2004, 142, 1300-1308. [CrossRef] 
27. Morrow, D.A.; Scirica, B.M.; Karwatowska-Prokopczuk, E.; Skene, A.; McCabe, C.H.; Braunwald, E. MERLIN-TIMI 36 Investigators Evaluation of a Novel Anti-Ischemic Agent in Acute Coronary Syndromes: Design and Rationale for the Metabolic Efficiency with Ranolazine for Less Ischemia in Non-ST-Elevation Acute Coronary Syndromes (MERLIN)-TIMI 36 Trial. Am. Heart J. 2006, 151, 1186.e1-1186.e9. [CrossRef]

28. Koren, M.J.; Crager, M.R.; Sweeney, M. Long-Term Safety of a Novel Antianginal Agent in Patients with Severe Chronic Stable Angina: The Ranolazine Open Label Experience (ROLE). J. Am. Coll. Cardiol. 2007, 49, 1027-1034. [CrossRef]

29. Wilson, S.R.; Scirica, B.M.; Braunwald, E.; Murphy, S.A.; Karwatowska-Prokopczuk, E.; Buros, J.L.; Chaitman, B.R.; Morrow, D.A Efficacy of Ranolazine in Patients with Chronic Angina Observations from the Randomized, Double-Blind, Placebo-Controlled MERLIN-TIMI (Metabolic Efficiency With Ranolazine for Less Ischemia in Non-ST-Segment Elevation Acute Coronary Syndromes) 36 Trial. J. Am. Coll. Cardiol. 2009, 53, 1510-1516. [CrossRef]

30. Murray, G.L.; Colombo, J. Ranolazine Improves Autonomic Balance in Heart Failure When Added to Guideline-Driven Therapy Heart Int. 2014, 9, 59-65. [CrossRef]

31. Murray, G.L. Ranolazine Is an Effective and Safe Treatment of Adults with Symptomatic Premature Ventricular Contractions Due to Triggered Ectopy. Int. J. Angiol. Off. Publ. Int. Coll. Angiol. Inc. 2016, 25, 247-251. [CrossRef] [PubMed]

32. Zeng, X.; Zhang, Y.; Lin, J.; Zheng, H.; Peng, J.; Huang, W. Efficacy and Safety of Ranolazine in Diabetic Patients: A Systematic Review and Meta-Analysis. Ann. Pharmacother. 2017, 52, 415-425. [CrossRef] [PubMed]

33. Olivotto, I.; Camici, P.G.; Merlini, P.A.; Rapezzi, C.; Patten, M.; Climent, V.; Sinagra, G.; Tomberli, B.; Marin, F.; Ehlermann, P.; et al. Efficacy of Ranolazine in Patients With Symptomatic Hypertrophic Cardiomyopathy: The RESTYLE-HCM Randomized, Double-Blind, Placebo-Controlled Study. Circ. Heart Fail. 2018, 11, e004124. [CrossRef]

34. Chaitman, B.R. Ranolazine for the Treatment of Chronic Angina and Potential Use in Other Cardiovascular Conditions. Circulation 2006, 113, 2462-2472. [CrossRef]

35. Szél, T.; Koncz, I.; Jost, N.; Baczkó, I.; Husti, Z.; Virág, L.; Bussek, A.; Wettwer, E.; Ravens, U.; Papp, J.G.; et al. Class I/B Antiarrhythmic Property of Ranolazine, a Novel Antianginal Agent, in Dog and Human Cardiac Preparations. Eur. J. Pharmacol. 2011, 662, 31-39. [CrossRef]

36. Guns, P.-J.; Johnson, D.M.; Weltens, E.; Lissens, J. Negative Electro-Mechanical Windows Are Required for Drug-Induced Torsades de Pointes in the Anesthetized Guinea Pig. J. Pharmacol. Toxicol. Methods 2012, 66, 125-134. [CrossRef]

37. Antoons, G.; Oros, A.; Beekman, J.D.M.; Engelen, M.A.; Houtman, M.J.C.; Belardinelli, L.; Stengl, M.; Vos, M.A. Late Na ${ }^{+}$Current Inhibition by Ranolazine Reduces Torsades de Pointes in the Chronic Atrioventricular Block Dog Model. J. Am. Coll. Cardiol. 2010, 55, 801-809. [CrossRef]

38. Wang, W.-Q.; Robertson, C.; Dhalla, A.K.; Belardinelli, L. Antitorsadogenic Effects of (\{+/-\})-N-(2,6-Dimethyl-Phenyl)-(4[2Hydroxy-3-(2-Methoxyphenoxy)Propyl]-1-Piperazine (Ranolazine) in Anesthetized Rabbits. J. Pharmacol. Exp. Ther. 2008, 325, 875-881. [CrossRef]

39. Wu, L.; Shryock, J.C.; Song, Y.; Li, Y.; Antzelevitch, C.; Belardinelli, L. Antiarrhythmic Effects of Ranolazine in a Guinea Pig in Vitro Model of Long-QT Syndrome. J. Pharmacol. Exp. Ther. 2004, 310, 599-605. [CrossRef]

40. Singh, B.N.; Wadhani, N. Antiarrhythmic and Proarrhythmic Properties of QT-Prolonging Antianginal Drugs. J. Cardiovasc. Pharmacol. Ther. 2004, 9 (Suppl. S1), S85-S97. [CrossRef]

41. Moss, A.J.; Zareba, W.; Schwarz, K.Q.; Rosero, S.; McNitt, S.; Robinson, J.L. Ranolazine Shortens Repolarization in Patients with Sustained Inward Sodium Current Due to Type-3 Long-QT Syndrome. J. Cardiovasc. Electrophysiol. 2008, 19, 1289-1293. [CrossRef] [PubMed]

42. Wang, Q.; Shen, J.; Splawski, I.; Atkinson, D.; Li, Z.; Robinson, J.L.; Moss, A.J.; Towbin, J.A.; Keating, M.T. SCN5A Mutations Associated with an Inherited Cardiac Arrhythmia, Long QT Syndrome. Cell 1995, 80, 805-811. [CrossRef]

43. Medeiros-Domingo, A.; Kaku, T.; Tester, D.J.; Iturralde-Torres, P.; Itty, A.; Ye, B.; Valdivia, C.; Ueda, K.; Canizales-Quinteros, S.; Tusié-Luna, M.T.; et al. SCN4B-Encoded Sodium Channel Beta4 Subunit in Congenital Long-QT Syndrome. Circulation 2007, 116, 134-142. [CrossRef] [PubMed]

44. Scirica, B.M.; Morrow, D.A.; Hod, H.; Murphy, S.A.; Belardinelli, L.; Hedgepeth, C.M.; Molhoek, P.; Verheugt, F.W.A.; Gersh, B.J.; McCabe, C.H.; et al. Effect of Ranolazine, an Antianginal Agent with Novel Electrophysiological Properties, on the Incidence of Arrhythmias in Patients with Non ST-Segment Elevation Acute Coronary Syndrome: Results from the Metabolic Efficiency With Ranolazine for Less Ischemia in Non ST-Elevation Acute Coronary Syndrome Thrombolysis in Myocardial Infarction 36 (MERLIN-TIMI 36) Randomized Controlled Trial. Circulation 2007, 116, 1647-1652. [CrossRef]

45. Scirica, B.M.; Belardinelli, L.; Chaitman, B.R.; Waks, J.W.; Volo, S.; Karwatowska-Prokopczuk, E.; Murphy, S.A.; Cheng, M.L.; Braunwald, E.; Morrow, D.A. Effect of Ranolazine on Atrial Fibrillation in Patients with Non-ST Elevation Acute Coronary Syndromes: Observations from the MERLIN-TIMI 36 Trial. Eur. Eur. Pacing Arrhythm. Card. Electrophysiol. J. Work. Groups Card. Pacing Arrhythm. Card. Cell. Electrophysiol. Eur. Soc. Cardiol. 2015, 17, 32-37. [CrossRef] [PubMed]

46. Murdock, D.K.; Overton, N.; Kersten, M.; Kaliebe, J.; Devecchi, F. The Effect of Ranolazine on Maintaining Sinus Rhythm in Patients with Resistant Atrial Fibrillation. Indian Pacing Electrophysiol. J. 2008, 8, 175-181.

47. Miles, R.H.; Passman, R.; Murdock, D.K. Comparison of Effectiveness and Safety of Ranolazine versus Amiodarone for Preventing Atrial Fibrillation after Coronary Artery Bypass Grafting. Am. J. Cardiol. 2011, 108, 673-676. [CrossRef] [PubMed] 
48. Reiffel, J.A.; Camm, A.J.; Belardinelli, L.; Zeng, D.; Karwatowska-Prokopczuk, E.; Olmsted, A.; Zareba, W.; Rosero, S.; Kowey, P.; HARMONY Investigators. The HARMONY Trial: Combined Ranolazine and Dronedarone in the Management of Paroxysmal Atrial Fibrillation: Mechanistic and Therapeutic Synergism. Circ. Arrhythm. Electrophysiol. 2015, 8, 1048-1056. [CrossRef]

49. Tsanaxidis, N.; Aidonidis, I.; Hatziefthimiou, A.; Daskalopoulou, S.S.; Giamouzis, G.; Triposkiadis, F.; Skoularigis, I. Ranolazine Added to Amiodarone Facilitates Earlier Conversion of Atrial Fibrillation Compared to Amiodarone-Only Therapy. Pacing Clin. Electrophysiol. 2017, 40, 372-378. [CrossRef]

50. Verrier, R.L.; Silva, A.F.G.; Bonatti, R.; Batatinha, J.A.P.; Nearing, B.D.; Liu, G.; Rajamani, S.; Zeng, D.; Belardinelli, L. Combined Actions of Ivabradine and Ranolazine Reduce Ventricular Rate during Atrial Fibrillation. J. Cardiovasc. Electrophysiol. 2015, 26, 329-335. [CrossRef]

51. Hammond, D.A.; Smotherman, C.; Jankowski, C.A.; Tan, S.; Osian, O.; Kraemer, D.; DeLosSantos, M. Short-Course of Ranolazine Prevents Postoperative Atrial Fibrillation Following Coronary Artery Bypass Grafting and Valve Surgeries. Clin. Res. Cardiol. Off. J. Ger. Card. Soc. 2015, 104, 410-417. [CrossRef]

52. De Ferrari, G.M.; Maier, L.S.; Mont, L.; Schwartz, P.J.; Simonis, G.; Leschke, M.; Gronda, E.; Boriani, G.; Darius, H.; Guillamón Torán, L.; et al. Ranolazine in the Treatment of Atrial Fibrillation: Results of the Dose-Ranging RAFFAELLO (Ranolazine in Atrial Fibrillation Following an ELectricaL CardiOversion) Study. Heart Rhythm 2015, 12, 872-878. [CrossRef] [PubMed]

53. Bunch, T.J.; Mahapatra, S.; Murdock, D.; Molden, J.; Weiss, J.P.; May, H.T.; Bair, T.L.; Mader, K.M.; Crandall, B.G.; Day, J.D.; et al. Ranolazine Reduces Ventricular Tachycardia Burden and ICD Shocks in Patients with Drug-Refractory ICD Shocks. Pacing Clin. Electrophysiol. 2011, 34, 1600-1606. [CrossRef] [PubMed]

54. Zareba, W.; Daubert, J.P.; Beck, C.A.; Huang, D.T.; Alexis, J.D.; Brown, M.W.; Pyykkonen, K.; McNitt, S.; Oakes, D.; Feng, C.; et al. Ranolazine in High-Risk Patients With Implanted Cardioverter-Defibrillators: The RAID Trial. J. Am. Coll. Cardiol. 2018, 72, 636-645. [CrossRef] [PubMed]

55. Rajamani, S.; El-Bizri, N.; Shryock, J.C.; Makielski, J.C.; Belardinelli, L. Use-Dependent Block of Cardiac Late Na ${ }^{+}$Current by Ranolazine. Heart Rhythm 2009, 6, 1625-1631. [CrossRef] [PubMed]

56. Maier, L.S.; Sossalla, S. The Late Na Current as a Therapeutic Target: Where Are We? J. Mol. Cell. Cardiol. 2013, 61, 44-50. [CrossRef] [PubMed]

57. Undrovinas, A.; Maltsev, V.A. Late Sodium Current Is a New Therapeutic Target to Improve Contractility and Rhythm in Failing Heart. Cardiovasc. Hematol. Agents Med. Chem. 2008, 6, 348-359. [CrossRef]

58. Chambers, J.C.; Zhao, J.; Terracciano, C.M.N.; Bezzina, C.R.; Zhang, W.; Kaba, R.; Navaratnarajah, M.; Lotlikar, A.; Sehmi, J.S.; Kooner, M.K.; et al. Genetic Variation in SCN10A Influences Cardiac Conduction. Nat. Genet. 2010, 42, 149-152. [CrossRef]

59. Sotoodehnia, N.; Isaacs, A.; de Bakker, P.I.W.; Dörr, M.; Newton-Cheh, C.; Nolte, I.M.; van der Harst, P.; Müller, M.; Eijgelsheim, M.; Alonso, A.; et al. Common Variants in 22 Loci Are Associated with QRS Duration and Cardiac Ventricular Conduction. Nat. Genet. 2010, 42, 1068-1076. [CrossRef]

60. Stroud, D.M.; Yang, T.; Bersell, K.; Kryshtal, D.O.; Nagao, S.; Shaffer, C.; Short, L.; Hall, L.; Atack, T.C.; Zhang, W.; et al. Contrasting Nav1.8 Activity in Scn10a-/- Ventricular Myocytes and the Intact Heart. J. Am. Heart Assoc. 2016, 5, e002946. [CrossRef]

61. Yang, T.; Atack, T.C.; Stroud, D.M.; Zhang, W.; Hall, L.; Roden, D.M. Blocking Scn10a Channels in Heart Reduces Late Sodium Current and Is Antiarrhythmic. Circ. Res. 2012, 111, 322-332. [CrossRef] [PubMed]

62. Saint, D.A.; Ju, Y.K.; Gage, P.W. A Persistent Sodium Current in Rat Ventricular Myocytes. J. Physiol. 1992, 453, 219-231. [CrossRef] [PubMed]

63. Shryock, J.C.; Song, Y.; Rajamani, S.; Antzelevitch, C.; Belardinelli, L. The Arrhythmogenic Consequences of Increasing Late INa in the Cardiomyocyte. Cardiovasc. Res. 2013, 99, 600-611. [CrossRef] [PubMed]

64. Gupta, T.; Khera, S.; Kolte, D.; Aronow, W.S.; Iwai, S. Antiarrhythmic Properties of Ranolazine: A Review of the Current Evidence. Int. J. Cardiol. 2015, 187, 66-74. [CrossRef]

65. Moreno, J.D.; Clancy, C.E. Pathophysiology of the Cardiac Late Na Current and Its Potential as a Drug Target. J. Mol. Cell. Cardiol. 2012, 52, 608-619. [CrossRef]

66. Noble, D.; Noble, P.J. Late Sodium Current in the Pathophysiology of Cardiovascular Disease: Consequences of Sodium-Calcium Overload. Heart Br. Card. Soc. 2006, 92 (Suppl. S4), iv1-iv5. [CrossRef]

67. Li, P.; Rudy, Y. A Model of Canine Purkinje Cell Electrophysiology and Ca(2+) Cycling: Rate Dependence, Triggered Activity, and Comparison to Ventricular Myocytes. Circ. Res. 2011, 109, 71-79. [CrossRef]

68. Belardinelli, L.; Giles, W.R.; Rajamani, S.; Karagueuzian, H.S.; Shryock, J.C. Cardiac Late Na ${ }^{+}$Current: Proarrhythmic Effects, Roles in Long QT Syndromes, and Pathological Relationship to CaMKII and Oxidative Stress. Heart Rhythm 2015, 12, 440-448. [CrossRef]

69. Bossu, A.; Houtman, M.J.C.; Meijborg, V.M.F.; Varkevisser, R.; Beekman, H.D.M.; Dunnink, A.; de Bakker, J.M.T.; Mollova, N.; Rajamani, S.; Belardinelli, L.; et al. Selective Late Sodium Current Inhibitor GS-458967 Suppresses Torsades de Pointes by Mostly Affecting Perpetuation but Not Initiation of the Arrhythmia. Br. J. Pharmacol. 2018, 175, 2470-2482. [CrossRef]

70. Fredj, S.; Lindegger, N.; Sampson, K.J.; Carmeliet, P.; Kass, R.S. Altered $\mathrm{Na}^{+}$Channels Promote Pause-Induced Spontaneous Diastolic Activity in Long QT Syndrome Type 3 Myocytes. Circ. Res. 2006, 99, 1225-1232. [CrossRef] 
71. Wu, L.; Ma, J.; Li, H.; Wang, C.; Grandi, E.; Zhang, P.; Luo, A.; Bers, D.M.; Shryock, J.C.; Belardinelli, L. Late Sodium Current Contributes to the Reverse Rate-Dependent Effect of IKr Inhibition on Ventricular Repolarization. Circulation 2011, 123, 1713-1720. [CrossRef]

72. Carlsson, L.; Almgren, O.; Duker, G. QTU-Prolongation and Torsades de Pointes Induced by Putative Class III Antiarrhythmic Agents in the Rabbit: Etiology and Interventions. J. Cardiovasc. Pharmacol. 1990, 16, 276-285. [CrossRef]

73. Sossalla, S.; Wallisch, N.; Toischer, K.; Sohns, C.; Vollmann, D.; Seegers, J.; Lüthje, L.; Maier, L.S.; Zabel, M. Effects of Ranolazine on Torsades de Pointes Tachycardias in a Healthy Isolated Rabbit Heart Model. Cardiovasc. Ther. 2014, 32, 170-177. [CrossRef]

74. Fredj, S.; Sampson, K.J.; Liu, H.; Kass, R.S. Molecular Basis of Ranolazine Block of LQT-3 Mutant Sodium Channels: Evidence for Site of Action. Br. J. Pharmacol. 2006, 148, 16-24. [CrossRef] [PubMed]

75. Burashnikov, A.; Di Diego, J.M.; Zygmunt, A.C.; Belardinelli, L.; Antzelevitch, C. Atrium-Selective Sodium Channel Block as a Strategy for Suppression of Atrial Fibrillation: Differences in Sodium Channel Inactivation between Atria and Ventricles and the Role of Ranolazine. Circulation 2007, 116, 1449-1457. [CrossRef]

76. Undrovinas, A.I.; Belardinelli, L.; Undrovinas, N.A.; Sabbah, H.N. Ranolazine Improves Abnormal Repolarization and Contraction in Left Ventricular Myocytes of Dogs with Heart Failure by Inhibiting Late Sodium Current. J. Cardiovasc. Electrophysiol. 2006, 17 (Suppl. S1), S169-S177. [CrossRef] [PubMed]

77. Antzelevitch, C.; Belardinelli, L. The Role of Sodium Channel Current in Modulating Transmural Dispersion of Repolarization and Arrhythmogenesis. J. Cardiovasc. Electrophysiol. 2006, 17 (Suppl. S1), S79-S85. [CrossRef] [PubMed]

78. Qi, D.; Yang, Z.; Robinson, V.M.; Li, J.; Gao, C.; Guo, D.; Kowey, P.R.; Yan, G.-X. Heterogeneous Distribution of INa-L Determines Interregional Differences in Rate Adaptation of Repolarization. Heart Rhythm 2015, 12, 1295-1303. [CrossRef] [PubMed]

79. Zygmunt, A.C.; Eddlestone, G.T.; Thomas, G.P.; Nesterenko, V.V.; Antzelevitch, C. Larger Late Sodium Conductance in M Cells Contributes to Electrical Heterogeneity in Canine Ventricle. Am. J. Physiol. Heart Circ. Physiol. 2001, 281, H689-H697. [CrossRef]

80. Kumar, K.; Nearing, B.D.; Bartoli, C.R.; Kwaku, K.F.; Belardinelli, L.; Verrier, R.L. Effect of Ranolazine on Ventricular Vulnerability and Defibrillation Threshold in the Intact Porcine Heart. J. Cardiovasc. Electrophysiol. 2008, 19, 1073-1079. [CrossRef]

81. Zhao, Z.; Fefelova, N.; Shanmugam, M.; Bishara, P.; Babu, G.J.; Xie, L.-H. Angiotensin II Induces Afterdepolarizations via Reactive Oxygen Species and Calmodulin Kinase II Signaling. J. Mol. Cell. Cardiol. 2011, 50, 128-136. [CrossRef]

82. Wu, L.; Rajamani, S.; Li, H.; January, C.T.; Shryock, J.C.; Belardinelli, L. Reduction of Repolarization Reserve Unmasks the Proarrhythmic Role of Endogenous Late Na ${ }^{+}$Current in the Heart. Am. J. Physiol. Heart Circ. Physiol. 2009, 297, H1048-H1057. [CrossRef] [PubMed]

83. Zareba, W.; Moss, A.J.; le Cessie, S. Dispersion of Ventricular Repolarization and Arrhythmic Cardiac Death in Coronary Artery Disease. Am. J. Cardiol. 1994, 74, 550-553. [CrossRef]

84. Weiss, J.N.; Garfinkel, A.; Karagueuzian, H.S.; Chen, P.-S.; Qu, Z. Early Afterdepolarizations and Cardiac Arrhythmias. Heart Rhythm 2010, 7, 1891-1899. [CrossRef] [PubMed]

85. Thireau, J.; Karam, S.; Roberge, S.; Roussel, J.; Aimond, F.; Cassan, C.; Gac, A.; Babuty, D.; Le Guennec, J.-Y.; Lacampagne, A.; et al. B-Adrenergic Blockade Combined with Subcutaneous B-Type Natriuretic Peptide: A Promising Approach to Reduce Ventricular Arrhythmia in Heart Failure? Heart Br. Card. Soc. 2014, 100, 833-841. [CrossRef] [PubMed]

86. Fischer, T.H.; Herting, J.; Mason, F.E.; Hartmann, N.; Watanabe, S.; Nikolaev, V.O.; Sprenger, J.U.; Fan, P.; Yao, L.; Popov, A.-F.; et al. Late INa Increases Diastolic SR-Ca ${ }^{2+}$-Leak in Atrial Myocardium by Activating PKA and CaMKII. Cardiovasc. Res. 2015, 107, 184-196. [CrossRef]

87. Wu, J.; Corr, P.B. Palmitoyl Carnitine Modifies Sodium Currents and Induces Transient Inward Current in Ventricular Myocytes Am. J. Physiol. 1994, 266, H1034-H1046. [CrossRef]

88. Viatchenko-Karpinski, S.; Kornyeyev, D.; El-Bizri, N.; Budas, G.; Fan, P.; Jiang, Z.; Yang, J.; Anderson, M.E.; Shryock, J.C.; Chang, C.-P.; et al. Intracellular $\mathrm{Na}^{+}$Overload Causes Oxidation of CaMKII and Leads to $\mathrm{Ca}^{2+}$ Mishandling in Isolated Ventricular Myocytes. J. Mol. Cell. Cardiol. 2014, 76, 247-256. [CrossRef]

89. Sag, C.M.; Mallwitz, A.; Wagner, S.; Hartmann, N.; Schotola, H.; Fischer, T.H.; Ungeheuer, N.; Herting, J.; Shah, A.M.; Maier, L.S.; et al. Enhanced Late INa Induces Proarrhythmogenic SR Ca Leak in a CaMKII-Dependent Manner. J. Mol. Cell. Cardiol. 2014, 76, 94-105. [CrossRef]

90. Undrovinas, N.A.; Maltsev, V.A.; Belardinelli, L.; Sabbah, H.N.; Undrovinas, A. Late Sodium Current Contributes to Diastolic Cell Ca2+ Accumulation in Chronic Heart Failure. J. Physiol. Sci. 2010, 60, 245-257. [CrossRef]

91. Wasserstrom, J.A.; Sharma, R.; O’Toole, M.J.; Zheng, J.; Kelly, J.E.; Shryock, J.; Belardinelli, L.; Aistrup, G.L. Ranolazine Antagonizes the Effects of Increased Late Sodium Current on Intracellular Calcium Cycling in Rat Isolated Intact Heart. J. Pharmacol. Exp. Ther. 2009, 331, 382-391. [CrossRef] [PubMed]

92. Guerra, F.; Romandini, A.; Barbarossa, A.; Belardinelli, L.; Capucci, A. Ranolazine for Rhythm Control in Atrial Fibrillation: A Systematic Review and Meta-Analysis. Int. J. Cardiol. 2017, 227, 284-291. [CrossRef] [PubMed]

93. Burashnikov, A.; Antzelevitch, C. Atrial-Selective Sodium Channel Block for the Treatment of Atrial Fibrillation. Expert Opin. Emerg. Drugs 2009, 14, 233-249. [CrossRef]

94. Ratte, A.; Wiedmann, F.; Kraft, M.; Katus, H.A.; Schmidt, C. Antiarrhythmic Properties of Ranolazine: Inhibition of Atrial Fibrillation Associated TASK-1 Potassium Channels. Front. Pharmacol. 2019, 10, 1367. [CrossRef] [PubMed] 
95. Caves, R.E.; Cheng, H.; Choisy, S.C.; Gadeberg, H.C.; Bryant, S.M.; Hancox, J.C.; James, A.F. Atrial-Ventricular Differences in Rabbit Cardiac Voltage-Gated Na+ Currents: Basis for Atrial-Selective Block by Ranolazine. Heart Rhythm 2017, 14, 1657-1664. [CrossRef] [PubMed]

96. Sossalla, S.; Kallmeyer, B.; Wagner, S.; Mazur, M.; Maurer, U.; Toischer, K.; Schmitto, J.D.; Seipelt, R.; Schöndube, F.A.; Hasenfuss, G.; et al. Altered $\mathrm{Na}^{+}$Currents in Atrial Fibrillation Effects of Ranolazine on Arrhythmias and Contractility in Human Atrial Myocardium. J. Am. Coll. Cardiol. 2010, 55, 2330-2342. [CrossRef]

97. Nesterenko, V.V.; Zygmunt, A.C.; Rajamani, S.; Belardinelli, L.; Antzelevitch, C. Mechanisms of Atrial-Selective Block of Na ${ }^{+}$ Channels by Ranolazine: II. Insights from a Mathematical Model. Am. J. Physiol. Heart Circ. Physiol. 2011, 301, H1615-H1624. [CrossRef]

98. Guo, D.; Young, L.; Wu, Y.; Belardinelli, L.; Kowey, P.R.; Yan, G.-X. Increased Late Sodium Current in Left Atrial Myocytes of Rabbits with Left Ventricular Hypertrophy: Its Role in the Genesis of Atrial Arrhythmias. Am. J. Physiol. Heart Circ. Physiol. 2010, 298, H1375-H1381. [CrossRef]

99. Song, Y.; Shryock, J.C.; Belardinelli, L. An Increase of Late Sodium Current Induces Delayed Afterdepolarizations and Sustained Triggered Activity in Atrial Myocytes. Am. J. Physiol. Heart Circ. Physiol. 2008, 294, H2031-H2039. [CrossRef]

100. Li, D.; Melnyk, P.; Feng, J.; Wang, Z.; Petrecca, K.; Shrier, A.; Nattel, S. Effects of Experimental Heart Failure on Atrial Cellular and Ionic Electrophysiology. Circulation 2000, 101, 2631-2638. [CrossRef]

101. Fischer, T.H.; Herting, J.; Tirilomis, T.; Renner, A.; Neef, S.; Toischer, K.; Ellenberger, D.; Förster, A.; Schmitto, J.D.; Gummert, J.; et al. $\mathrm{Ca}^{2+} /$ Calmodulin-Dependent Protein Kinase II and Protein Kinase A Differentially Regulate Sarcoplasmic Reticulum Ca ${ }^{2+}$ Leak in Human Cardiac Pathology. Circulation 2013, 128, 970-981. [CrossRef]

102. Kirchhof, P.; Eckardt, L.; Franz, M.R.; Mönnig, G.; Loh, P.; Wedekind, H.; Schulze-Bahr, E.; Breithardt, G.; Haverkamp, W. Prolonged Atrial Action Potential Durations and Polymorphic Atrial Tachyarrhythmias in Patients with Long QT Syndrome. J. Cardiovasc. Electrophysiol. 2003, 14, 1027-1033. [CrossRef] [PubMed]

103. Verheule, S.; Wilson, E.; Everett, T.; Shanbhag, S.; Golden, C.; Olgin, J. Alterations in Atrial Electrophysiology and Tissue Structure in a Canine Model of Chronic Atrial Dilatation Due to Mitral Regurgitation. Circulation 2003, 107, 2615-2622. [CrossRef] [PubMed]

104. Lip, G.Y.H.; Fauchier, L.; Freedman, S.B.; Van Gelder, I.; Natale, A.; Gianni, C.; Nattel, S.; Potpara, T.; Rienstra, M.; Tse, H.-F.; et al. Atrial Fibrillation. Nat. Rev. Dis. Primer 2016, 2, 16016. [CrossRef] [PubMed]

105. Kumar, K.; Nearing, B.D.; Carvas, M.; Nascimento, B.C.G.; Acar, M.; Belardinelli, L.; Verrier, R.L. Ranolazine Exerts Potent Effects on Atrial Electrical Properties and Abbreviates Atrial Fibrillation Duration in the Intact Porcine Heart. J. Cardiovasc. Electrophysiol. 2009, 20, 796-802. [CrossRef]

106. Sicouri, S.; Belardinelli, L.; Antzelevitch, C. Effect of Autonomic Influences to Induce Triggered Activity in Muscular Sleeves Extending into the Coronary Sinus of the Canine Heart and Its Suppression by Ranolazine. J. Cardiovasc. Electrophysiol. 2019, 30, 230-238. [CrossRef] [PubMed]

107. Aidonidis, I.; Doulas, K.; Hatziefthimiou, A.; Tagarakis, G.; Simopoulos, V.; Rizos, I.; Tsilimingas, N.; Molyvdas, P.-A. RanolazineInduced Postrepolarization Refractoriness Suppresses Induction of Atrial Flutter and Fibrillation in Anesthetized Rabbits. J. Cardiovasc. Pharmacol. Ther. 2013, 18, 94-101. [CrossRef]

108. Youn, J.-Y.; Zhang, J.; Zhang, Y.; Chen, H.; Liu, D.; Ping, P.; Weiss, J.N.; Cai, H. Oxidative Stress in Atrial Fibrillation: An Emerging Role of NADPH Oxidase. J. Mol. Cell. Cardiol. 2013, 62, 72-79. [CrossRef]

109. Song, Y.; Shryock, J.C.; Belardinelli, L. A Slowly Inactivating Sodium Current Contributes to Spontaneous Diastolic Depolarization of Atrial Myocytes. Am. J. Physiol. Heart Circ. Physiol. 2009, 297, H1254-H1262. [CrossRef]

110. Bhimani, A.A.; Yasuda, T.; Sadrpour, S.A.; Khrestian, C.M.; Lee, S.; Zeng, D.; Belardinelli, L.; Waldo, A.L. Ranolazine Terminates Atrial Flutter and Fibrillation in a Canine Model. Heart Rhythm 2014, 11, 1592-1599. [CrossRef]

111. Sicouri, S.; Glass, A.; Belardinelli, L.; Antzelevitch, C. Antiarrhythmic Effects of Ranolazine in Canine Pulmonary Vein Sleeve Preparations. Heart Rhythm 2008, 5, 1019-1026. [CrossRef] [PubMed]

112. Burashnikov, A.; Sicouri, S.; Di Diego, J.M.; Belardinelli, L.; Antzelevitch, C. Synergistic Effect of the Combination of Ranolazine and Dronedarone to Suppress Atrial Fibrillation. J. Am. Coll. Cardiol. 2010, 56, 1216-1224. [CrossRef] [PubMed]

113. Carstensen, H.; Kjær, L.; Haugaard, M.M.; Flethøj, M.; Hesselkilde, E.Z.; Kanters, J.K.; Pehrson, S.; Buhl, R.; Jespersen, T. Antiarrhythmic Effects of Combining Dofetilide and Ranolazine in a Model of Acutely Induced Atrial Fibrillation in Horses. J. Cardiovasc. Pharmacol. 2018, 71, 26-35. [CrossRef] [PubMed]

114. Jarecki, B.W.; Sheets, P.L.; Jackson, J.O.; Cummins, T.R. Paroxysmal Extreme Pain Disorder Mutations within the D3/S4-S5 Linker of Nav1.7 Cause Moderate Destabilization of Fast Inactivation. J. Physiol. 2008, 586, 4137-4153. [CrossRef]

115. Theile, J.W.; Cummins, T.R. Recent Developments Regarding Voltage-Gated Sodium Channel Blockers for the Treatment of Inherited and Acquired Neuropathic Pain Syndromes. Front. Pharmacol. 2011, 2, 54. [CrossRef]

116. Kahlig, K.M.; Lepist, I.; Leung, K.; Rajamani, S.; George, A.L. Ranolazine Selectively Blocks Persistent Current Evoked by Epilepsy-Associated Nav1.1 Mutations. Br. J. Pharmacol. 2010, 161, 1414-1426. [CrossRef]

117. Peters, C.H.; Sokolov, S.; Rajamani, S.; Ruben, P.C. Effects of the Antianginal Drug, Ranolazine, on the Brain Sodium Channel $\mathrm{Na}(\mathrm{V}) 1.2$ and Its Modulation by Extracellular Protons. Br. J. Pharmacol. 2013, 169, 704-716. [CrossRef] [PubMed]

118. Bae, H.J.; Lee, Y.S.; Kang, D.W.; Koo, J.S.; Yoon, B.W.; Roh, J.K.; Gu, J.S. Neuroprotective Effect of Low Dose Riluzole in Gerbil Model of Transient Global Ischemia. Neurosci. Lett. 2000, 294, 29-32. [CrossRef] 
119. Baptiste, D.C.; Fehlings, M.G. Pharmacological Approaches to Repair the Injured Spinal Cord. J. Neurotrauma 2006, 23, 318-334. [CrossRef]

120. Schwartz, G.; Fehlings, M.G. Evaluation of the Neuroprotective Effects of Sodium Channel Blockers after Spinal Cord Injury: Improved Behavioral and Neuroanatomical Recovery with Riluzole. J. Neurosurg. 2001, 94, 245-256. [CrossRef]

121. Anderson, L.L.; Thompson, C.H.; Hawkins, N.A.; Nath, R.D.; Petersohn, A.A.; Rajamani, S.; Bush, W.S.; Frankel, W.N.; Vanoye, C.G.; Kearney, J.A.; et al. Antiepileptic Activity of Preferential Inhibitors of Persistent Sodium Current. Epilepsia 2014, 55, 1274-1283. [CrossRef] [PubMed]

122. Belardinelli, L.; Liu, G.; Smith-Maxwell, C.; Wang, W.-Q.; El-Bizri, N.; Hirakawa, R.; Karpinski, S.; Li, C.H.; Hu, L.; Li, X.-J.; et al. A Novel, Potent, and Selective Inhibitor of Cardiac Late Sodium Current Suppresses Experimental Arrhythmias. J. Pharmacol. Exp. Ther. 2013, 344, 23-32. [CrossRef] [PubMed]

123. Sicouri, S.; Belardinelli, L.; Antzelevitch, C. Antiarrhythmic Effects of the Highly Selective Late Sodium Channel Current Blocker GS-458967. Heart Rhythm 2013, 10, 1036-1043. [CrossRef]

124. Zipes, D.P. Heart-Brain Interactions in Cardiac Arrhythmias: Role of the Autonomic Nervous System. Cleve. Clin. J. Med. 2008, 75 Suppl 2, S94-S96. [CrossRef]

125. Estacion, M.; Waxman, S.G.; Dib-Hajj, S.D. Effects of Ranolazine on Wild-Type and Mutant HNav1.7 Channels and on DRG Neuron Excitability. Mol. Pain 2010, 6, 35. [CrossRef]

126. Nodera, H.; Rutkove, S.B. Changes of the Peripheral Nerve Excitability in Vivo Induced by the Persistent Na+ Current Blocker Ranolazine. Neurosci. Lett. 2012, 518, 36-40. [CrossRef]

127. Gould, H.J.; Garrett, C.; Donahue, R.R.; Paul, D.; Diamond, I.; Taylor, B.K. Ranolazine Attenuates Behavioral Signs of Neuropathic Pain. Behav. Pharmacol. 2009, 20, 755-758. [CrossRef]

128. Wang, G.K.; Calderon, J.; Wang, S.-Y. State- and Use-Dependent Block of Muscle Nav1.4 and Neuronal Nav1.7 Voltage-Gated Na ${ }^{+}$ Channel Isoforms by Ranolazine. Mol. Pharmacol. 2008, 73, 940-948. [CrossRef]

129. Aman, T.K.; Grieco-Calub, T.M.; Chen, C.; Rusconi, R.; Slat, E.A.; Isom, L.L.; Raman, I.M. Regulation of Persistent Na Current by Interactions between Beta Subunits of Voltage-Gated Na Channels. J. Neurosci. Off. J. Soc. Neurosci. 2009, 29, 2027-2042 [CrossRef]

130. Mishra, S.; Reznikov, V.; Maltsev, V.A.; Undrovinas, N.A.; Sabbah, H.N.; Undrovinas, A. Contribution of Sodium Channel Neuronal Isoform Nav1.1 to Late Sodium Current in Ventricular Myocytes from Failing Hearts. J. Physiol. 2015, 593, 1409-1427. [CrossRef] [PubMed]

131. Welch, N.C.; Lin, W.; Juranka, P.F.; Morris, C.E.; Stys, P.K. Traditional AMPA Receptor Antagonists Partially Block Na v1.6Mediated Persistent Current. Neuropharmacology 2008, 55, 1165-1171. [CrossRef] [PubMed]

132. Murray, G.L.; Colombo, J. Ranolazine Preserves and Improves Left Ventricular Ejection Fraction and Autonomic Measures When Added to Guideline-Driven Therapy in Chronic Heart Failure. Heart Int. 2014, 9, 66-73. [CrossRef] [PubMed]

133. Teng, S.; Ren, Z.; Zhao, K. Vagal Stimulation Facilitates Improving Effects of Ranolazine on Cardiac Function in Rats with Chronic Ischemic Heart Failure. Curr. Mol. Med. 2018, 18, 36-43. [CrossRef] [PubMed]

134. Feng, G.; Yang, Y.; Chen, J.; Wu, Z.; Zheng, Y.; Li, W.; Dai, W.; Guan, P.; Zhong, C. Ranolazine Attenuated Heightened Plasma Norepinephrine and B-Type Natriuretic Peptide-45 in Improving Cardiac Function in Rats with Chronic Ischemic Heart Failure. Am. J. Transl. Res. 2016, 8, 1295-1301.

135. Aldakkak, M.; Camara, A.K.S.; Heisner, J.S.; Yang, M.; Stowe, D.F. Ranolazine Reduces Ca ${ }^{2+}$ Overload and Oxidative Stress and Improves Mitochondrial Integrity to Protect against Ischemia Reperfusion Injury in Isolated Hearts. Pharmacol. Res. 2011, 64, 381-392. [CrossRef]

136. Aldasoro, M.; Guerra-Ojeda, S.; Aguirre-Rueda, D.; Mauricio, M.D.; Vila, J.M.; Marchio, P.; Iradi, A.; Aldasoro, C.; Jorda, A.; Obrador, E.; et al. Effects of Ranolazine on Astrocytes and Neurons in Primary Culture. PLoS ONE 2016, 11, e0150619. [CrossRef]

137. Chang, C.-J.; Cheng, C.-C.; Yang, T.-F.; Chen, Y.-C.; Lin, Y.-K.; Chen, S.-A.; Chen, Y.-J. Selective and Non-Selective Non-Steroidal Anti-Inflammatory Drugs Differentially Regulate Pulmonary Vein and Atrial Arrhythmogenesis. Int. J. Cardiol. 2015, 184, 559-567. [CrossRef]

138. Tocchetti, C.G.; Carpi, A.; Coppola, C.; Quintavalle, C.; Rea, D.; Campesan, M.; Arcari, A.; Piscopo, G.; Cipresso, C.; Monti, M.G.; et al. Ranolazine Protects from Doxorubicin-Induced Oxidative Stress and Cardiac Dysfunction. Eur. J. Heart Fail. 2014, 16, 358-366. [CrossRef]

139. Wang, G.-T.; Li, H.; Yu, Z.-Q.; He, X.-N. Effects of Ranolazine on Cardiac Function in Rats with Heart Failure. Eur. Rev. Med. Pharmacol. Sci. 2019, 23, 9625-9632. [CrossRef]

140. Clerc, O.F.; Haaf, P.; Buechel, R.R.; Gaemperli, O.; Zellweger, M.J. New Therapies to Modulate Post-Infarction Inflammatory Alterations in the Myocardium: State of the Art and Forthcoming Applications. Curr. Radiopharm. 2021, 14, 273-299. [CrossRef]

141. Paredes-Carbajal, M.C.; Monsalvo, I.; Hernández-Díaz, C.; Regla, I.; Demare, P.; Mascher, D. Effects of Ranolazine on Vasomotor Responses of Rat Aortic Rings. Arch. Med. Res. 2013, 44, 8-12. [CrossRef] [PubMed]

142. Virsolvy, A.; Farah, C.; Pertuit, N.; Kong, L.; Lacampagne, A.; Reboul, C.; Aimond, F.; Richard, S. Antagonism of Nav Channels and A1-Adrenergic Receptors Contributes to Vascular Smooth Muscle Effects of Ranolazine. Sci. Rep. 2015, 5, 17969. [CrossRef]

143. Khazraei, H.; Mirkhani, H.; Purkhosrow, A. Vasorelaxant Effect of Ranolazine on Isolated Normal and Diabetic Rat Aorta: A Study of Possible Mechanisms. Acta Physiol. Hung. 2013, 100, 153-162. [CrossRef] [PubMed] 
144. Stone, P.H.; Chaitman, B.R.; Stocke, K.; Sano, J.; DeVault, A.; Koch, G.G. The Anti-Ischemic Mechanism of Action of Ranolazine in Stable Ischemic Heart Disease. J. Am. Coll. Cardiol. 2010, 56, 934-942. [CrossRef]

145. Malavaki, C.; Hatziefthimiou, A.; Daskalopoulou, S.S.; Stefanidis, I.; Karatzaferi, C.; Aidonidis, I. Ranolazine Enhances Nicardipine-Induced Relaxation of Alpha1-Adrenoceptor-Mediated Contraction on Isolated Rabbit Aorta. Acta Cardiol. 2015, 70, 157-162. [CrossRef]

146. Ahmed, B.; Mondragon, J.; Sheldon, M.; Clegg, S. Impact of Ranolazine on Coronary Microvascular Dysfunction (MICRO) Study. Cardiovasc. Revasculariz. Med. Mol. Interv. 2017, 18, 431-435. [CrossRef] [PubMed]

147. Rambarat, C.A.; Elgendy, I.Y.; Handberg, E.M.; Bairey Merz, C.N.; Wei, J.; Minissian, M.B.; Nelson, M.D.; Thomson, L.E.J.; Berman, D.S.; Shaw, L.J.; et al. Late Sodium Channel Blockade Improves Angina and Myocardial Perfusion in Patients with Severe Coronary Microvascular Dysfunction: Women's Ischemia Syndrome Evaluation-Coronary Vascular Dysfunction Ancillary Study. Int. J. Cardiol. 2019, 276, 8-13. [CrossRef]

148. Zhu, H.; Xu, X.; Fang, X.; Zheng, J.; Zhao, Q.; Chen, T.; Huang, J. Effects of the Antianginal Drugs Ranolazine, Nicorandil, and Ivabradine on Coronary Microvascular Function in Patients With Nonobstructive Coronary Artery Disease: A Meta-Analysis of Randomized Controlled Trials. Clin. Ther. 2019, 41, 2137-2152. [CrossRef]

149. Lamendola, P.; Nerla, R.; Pitocco, D.; Villano, A.; Scavone, G.; Stazi, A.; Russo, G.; Di Franco, A.; Sestito, A.; Ghirlanda, G.; et al. Effect of Ranolazine on Arterial Endothelial Function in Patients with Type 2 Diabetes Mellitus. Atherosclerosis 2013, 226, 157-160. [CrossRef]

150. Rehberger-Likozar, A.; Šebeštjen, M. Influence of Trimetazidine and Ranolazine on Endothelial Function in Patients with Ischemic Heart Disease. Coron. Artery Dis. 2015, 26, 651-656. [CrossRef]

151. Fort, A.; Cordaillat, M.; Thollon, C.; Salazar, G.; Mechaly, I.; Villeneuve, N.; Vilaine, J.-P.; Richard, S.; Virsolvy, A. New Insights in the Contribution of Voltage-Gated Na(v) Channels to Rat Aorta Contraction. PLoS ONE 2009, 4, e7360. [CrossRef] [PubMed]

152. Nieminen, T.; Tavares, C.A.M.; Pegler, J.R.M.; Belardinelli, L.; Verrier, R.L. Ranolazine Injection into Coronary or Femoral Arteries Exerts Marked, Transient Regional Vasodilation without Systemic Hypotension in an Intact Porcine Model. Circ. Cardiovasc. Interv. 2011, 4, 481-487. [CrossRef] [PubMed]

153. Deng, C.-Y.; Kuang, S.-J.; Rao, F.; Yang, H.; Fang, X.-H.; Shan, Z.-X.; Li, X.-H.; Zhou, Z.-L.; Lin, Q.-X.; Yang, M.; et al. Effect of Ranolazine on Rat Intrarenal Arteries in Vitro. Eur. J. Pharmacol. 2012, 683, 211-216. [CrossRef] [PubMed]

154. Marchio, P.; Guerra-Ojeda, S.; Aldasoro, M.; Valles, S.L.; Martín-Gonzalez, I.; Martínez-León, J.B.; Mauricio, M.D.; Vila, J.M Relaxant and Antiadrenergic Effects of Ranolazine in Human Saphenous Vein. Eur. J. Cardio-Thorac. Surg. Off. J. Eur. Assoc. Cardio-Thorac. Surg. 2020, 58, 277-285. [CrossRef] [PubMed]

155. Lee, J.C.; Kim, K.C.; Choe, S.Y.; Hong, Y.M. Reduced Immunoreactivities of B-Type Natriuretic Peptide in Pulmonary Arterial Hypertension Rats after Ranolazine Treatment. Anat. Cell Biol. 2016, 49, 7-14. [CrossRef]

156. Liles, J.T.; Hoyer, K.; Oliver, J.; Chi, L.; Dhalla, A.K.; Belardinelli, L. Ranolazine Reduces Remodeling of the Right Ventricle and Provoked Arrhythmias in Rats with Pulmonary Hypertension. J. Pharmacol. Exp. Ther. 2015, 353, 480-489. [CrossRef]

157. Khan, S.S.; Cuttica, M.J.; Beussink-Nelson, L.; Kozyleva, A.; Sanchez, C.; Mkrdichian, H.; Selvaraj, S.; Dematte, J.E.; Lee, D.C.; Shah, S.J. Effects of Ranolazine on Exercise Capacity, Right Ventricular Indices, and Hemodynamic Characteristics in Pulmonary Arterial Hypertension: A Pilot Study. Pulm. Circ. 2015, 5, 547-556. [CrossRef]

158. Gomberg-Maitland, M.; Schilz, R.; Mediratta, A.; Addetia, K.; Coslet, S.; Thomeas, V.; Gillies, H.; Oudiz, R.J. Phase I Safety Study of Ranolazine in Pulmonary Arterial Hypertension. Pulm. Circ. 2015, 5, 691-700. [CrossRef]

159. Han, Y.; Forfia, P.R.; Vaidya, A.; Mazurek, J.A.; Park, M.H.; Ramani, G.; Chan, S.Y.; Waxman, A.B. Rationale and Design of the Ranolazine PH-RV Study: A Multicentred Randomised and Placebo-Controlled Study of Ranolazine to Improve RV Function in Patients with Non-Group 2 Pulmonary Hypertension. Open Heart 2018, 5, e000736. [CrossRef]

160. Han, Y.; Forfia, P.; Vaidya, A.; Mazurek, J.A.; Park, M.H.; Ramani, G.; Chan, S.Y.; Waxman, A.B. Ranolazine Improves Right Ventricular Function in Patients With Precapillary Pulmonary Hypertension: Results From a Double-Blind, Randomized, PlaceboControlled Trial. J. Card. Fail. 2021, 27, 253-257. [CrossRef]

161. Quignard, J.F.; Ryckwaert, F.; Albat, B.; Nargeot, J.; Richard, S. A Novel Tetrodotoxin-Sensitive Na ${ }^{+}$Current in Cultured Human Coronary Myocytes. Circ. Res. 1997, 80, 377-382. [CrossRef] [PubMed]

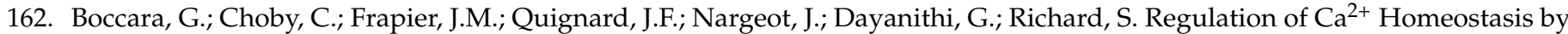
Atypical $\mathrm{Na}^{+}$Currents in Cultured Human Coronary Myocytes. Circ. Res. 1999, 85, 606-613. [CrossRef]

163. Kuriyama, H.; Kitamura, K.; Nabata, H. Pharmacological and Physiological Significance of Ion Channels and Factors That Modulate Them in Vascular Tissues. Pharmacol. Rev. 1995, 47, 387-573. [PubMed]

164. Okabe, K.; Kitamura, K.; Kuriyama, H. The Existence of a Highly Tetrodotoxin Sensitive Na Channel in Freshly Dispersed Smooth Muscle Cells of the Rabbit Main Pulmonary Artery. Pflugers Arch. 1988, 411, 423-428. [CrossRef] [PubMed]

165. Cox, R.H.; Zhou, Z.; Tulenko, T.N. Voltage-Gated Sodium Channels in Human Aortic Smooth Muscle Cells. J. Vasc. Res. 1998, 35, 310-317. [CrossRef]

166. Choby, C.; Mangoni, M.E.; Boccara, G.; Nargeot, J.; Richard, S. Evidence for Tetrodotoxin-Sensitive Sodium Currents in Primary Cultured Myocytes from Human, Pig and Rabbit Arteries. Pflugers Arch. 2000, 440, 149-152. [CrossRef]

167. Meguro, K.; Iida, H.; Takano, H.; Morita, T.; Sata, M.; Nagai, R.; Nakajima, T. Function and Role of Voltage-Gated Sodium Channel NaV1.7 Expressed in Aortic Smooth Muscle Cells. Am. J. Physiol. Heart Circ. Physiol. 2009, 296, H211-H219. [CrossRef] 
168. Jo, T.; Nagata, T.; Iida, H.; Imuta, H.; Iwasawa, K.; Ma, J.; Hara, K.; Omata, M.; Nagai, R.; Takizawa, H.; et al. Voltage-Gated Sodium Channel Expressed in Cultured Human Smooth Muscle Cells: Involvement of SCN9A. FEBS Lett. 2004, 567, 339-343. [CrossRef]

169. Rocchetti, M.; Sala, L.; Rizzetto, R.; Staszewsky, L.I.; Alemanni, M.; Zambelli, V.; Russo, I.; Barile, L.; Cornaghi, L.; Altomare, C.; et al. Ranolazine Prevents INaL Enhancement and Blunts Myocardial Remodelling in a Model of Pulmonary Hypertension. Cardiovasc. Res. 2014, 104, 37-48. [CrossRef]

170. Platoshyn, O.; Remillard, C.V.; Fantozzi, I.; Sison, T.; Yuan, J.X.-J. Identification of Functional Voltage-Gated Na(+) Channels in Cultured Human Pulmonary Artery Smooth Muscle Cells. Pflugers Arch. 2005, 451, 380-387. [CrossRef]

171. Meyer, N.; Tran, O.; Hartsfield, C.; Nguyen, L.; Kazi, D.S.; Koch, B. Revascularization Rates and Associated Costs in Patients With Stable Ischemic Heart Disease Initiating Ranolazine Versus Traditional Antianginals as Add-on Therapy. Am. J. Cardiol. 2019, 123, 1602-1609. [CrossRef]

172. Lopaschuk, G.D. Metabolic Modulators in Heart Disease: Past, Present, and Future. Can. J. Cardiol. 2017, 33, 838-849. [CrossRef]

173. McCormack, J.G.; Stanley, W.C.; Wolff, A.A. Ranolazine: A Novel Metabolic Modulator for the Treatment of Angina. Gen. Pharmacol. 1998, 30, 639-645. [CrossRef]

174. McCormack, J.G.; Barr, R.L.; Wolff, A.A.; Lopaschuk, G.D. Ranolazine Stimulates Glucose Oxidation in Normoxic, Ischemic, and Reperfused Ischemic Rat Hearts. Circulation 1996, 93, 135-142. [CrossRef] [PubMed]

175. Gralinski, M.R.; Black, S.C.; Kilgore, K.S.; Chou, A.Y.; McCormack, J.G.; Lucchesi, B.R. Cardioprotective Effects of Ranolazine (RS-43285) in the Isolated Perfused Rabbit Heart. Cardiovasc. Res. 1994, 28, 1231-1237. [CrossRef] [PubMed]

176. Arnold, S.V.; McGuire, D.K.; Spertus, J.A.; Li, Y.; Yue, P.; Ben-Yehuda, O.; Belardinelli, L.; Jones, P.G.; Olmsted, A.; Chaitman, B.R.; et al. Effectiveness of Ranolazine in Patients with Type 2 Diabetes Mellitus and Chronic Stable Angina According to Baseline Hemoglobin A1c. Am. Heart J. 2014, 168, 457-465. [CrossRef] [PubMed]

177. Greiner, L.; Hurren, K.; Brenner, M. Ranolazine and Its Effects on Hemoglobin A1C. Ann. Pharmacother. 2016, 50, 410-415. [CrossRef]

178. Teoh, I.H.; Banerjee, M. Effect of Ranolazine on Glycaemia in Adults with and without Diabetes: A Meta-Analysis of Randomised Controlled Trials. Open Heart 2018, 5, e000706. [CrossRef]

179. Rosano, G.M.C.; Vitale, C.; Volterrani, M. Pharmacological Management of Chronic Stable Angina: Focus on Ranolazine. Cardiovasc. Drugs Ther. 2016, 30, 393-398. [CrossRef]

180. Gilbert, B.W.; Sherard, M.; Little, L.; Branstetter, J.; Meister, A.; Huffman, J. Antihyperglycemic and Metabolic Effects of Ranolazine in Patients With Diabetes Mellitus. Am. J. Cardiol. 2018, 121, 509-512. [CrossRef]

181. Rousseau, M.F.; Pouleur, H.; Cocco, G.; Wolff, A.A. Comparative Efficacy of Ranolazine versus Atenolol for Chronic Angina Pectoris. Am. J. Cardiol. 2005, 95, 311-316. [CrossRef] [PubMed]

182. Jain, D.; Dasgupta, P.; Hughes, L.O.; Lahiri, A.; Raftery, E.B. Ranolazine (RS-43285): A Preliminary Study of a New Anti-Anginal Agent with Selective Effect on Ischaemic Myocardium. Eur. J. Clin. Pharmacol. 1990, 38, 111-114. [CrossRef] [PubMed]

183. Cocco, G.; Rousseau, M.F.; Bouvy, T.; Cheron, P.; Williams, G.; Detry, J.M.; Pouleur, H. Effects of a New Metabolic Modulator, Ranolazine, on Exercise Tolerance in Angina Pectoris Patients Treated with Beta-Blocker or Diltiazem. J. Cardiovasc. Pharmacol. 1992, 20, 131-138. [PubMed]

184. Hawash, A.A.; Voss, A.A.; Rich, M.M. Inhibiting Persistent Inward Sodium Currents Prevents Myotonia. Ann. Neurol. 2017, 82, 385-395. [CrossRef] [PubMed]

185. Myers, J.H.; Denman, K.; DuPont, C.; Hawash, A.A.; Novak, K.R.; Koesters, A.; Grabner, M.; Dayal, A.; Voss, A.A.; Rich, M.M. The Mechanism Underlying Transient Weakness in Myotonia Congenita. eLife 2021, 10, e65691. [CrossRef] [PubMed]

186. Novak, K.R.; Norman, J.; Mitchell, J.R.; Pinter, M.J.; Rich, M.M. Sodium Channel Slow Inactivation as a Therapeutic Target for Myotonia Congenita. Ann. Neurol. 2015, 77, 320-332. [CrossRef]

187. Lorusso, S.; Kline, D.; Bartlett, A.; Freimer, M.; Agriesti, J.; Hawash, A.A.; Rich, M.M.; Kissel, J.T.; David Arnold, W. Open-Label Trial of Ranolazine for the Treatment of Paramyotonia Congenita. Muscle Nerve 2019, 59, 240-243. [CrossRef]

188. Arnold, W.D.; Kline, D.; Sanderson, A.; Hawash, A.A.; Bartlett, A.; Novak, K.R.; Rich, M.M.; Kissel, J.T. Open-Label Trial of Ranolazine for the Treatment of Myotonia Congenita. Neurology 2017, 89, 710-713. [CrossRef]

189. El-Bizri, N.; Kahlig, K.M.; Shyrock, J.C.; George, A.L.; Belardinelli, L.; Rajamani, S. Ranolazine Block of Human Na v 1.4 Sodium Channels and Paramyotonia Congenita Mutants. Channels Austin Tex. 2011, 5, 161-172. [CrossRef]

190. Koltai, T. Voltage-Gated Sodium Channel as a Target for Metastatic Risk Reduction with Re-Purposed Drugs. F1000Research 2015, 4, 297. [CrossRef]

191. Roger, S.; Potier, M.; Vandier, C.; Besson, P.; Le Guennec, J.-Y. Voltage-Gated Sodium Channels: New Targets in Cancer Therapy? Curr. Pharm. Des. 2006, 12, 3681-3695. [CrossRef] [PubMed]

192. Fraser, S.P.; Onkal, R.; Theys, M.; Bosmans, F.; Djamgoz, M.B.A. Neonatal NaV 1.5 Channels: Pharmacological Distinctiveness of a Cancer-Related Voltage-Gated Sodium Channel Splice Variant. Br. J. Pharmacol. 2021. [CrossRef] [PubMed]

193. Fuchs, E.; Messerer, D.A.C.; Karpel-Massler, G.; Fauler, M.; Zimmer, T.; Jungwirth, B.; Föhr, K.J. Block of Voltage-Gated Sodium Channels as a Potential Novel Anti-Cancer Mechanism of TIC10. Front. Pharmacol. 2021, 12, 737637. [CrossRef]

194. Brackenbury, W.J. Voltage-Gated Sodium Channels and Metastatic Disease. Channels Austin Tex. 2012, 6, 352-361. [CrossRef]

195. Djamgoz, M.B.A.; Onkal, R. Persistent Current Blockers of Voltage-Gated Sodium Channels: A Clinical Opportunity for Controlling Metastatic Disease. Recent Patents Anticancer Drug Discov. 2013, 8, 66-84. [CrossRef] 
196. Wang, J.; Lu, Z.; Wu, C.; Li, Y.; Kong, Y.; Zhou, R.; Shi, K.; Guo, J.; Li, N.; Liu, J.; et al. Evaluation of the Anticancer and Anti-Metastasis Effects of Novel Synthetic Sodium Channel Blockers in Prostate Cancer Cells in Vitro and in Vivo. Prostate 2019, 79, 62-72. [CrossRef] [PubMed]

197. Driffort, V.; Gillet, L.; Bon, E.; Marionneau-Lambot, S.; Oullier, T.; Joulin, V.; Collin, C.; Pagès, J.-C.; Jourdan, M.-L.; Chevalier, S.; et al. Ranolazine Inhibits NaV1.5-Mediated Breast Cancer Cell Invasiveness and Lung Colonization. Mol. Cancer 2014, 13, 264. [CrossRef]

198. Bugan, I.; Kucuk, S.; Karagoz, Z.; Fraser, S.P.; Kaya, H.; Dodson, A.; Foster, C.S.; Altun, S.; Djamgoz, M.B.A. Anti-Metastatic Effect of Ranolazine in an in Vivo Rat Model of Prostate Cancer, and Expression of Voltage-Gated Sodium Channel Protein in Human Prostate. Prostate Cancer Prostatic Dis. 2019, 22, 569-579. [CrossRef]

199. Guth, A.; Monk, E.; Agarwal, R.; Bergman, B.C.; Zemski-Berry, K.A.; Minic, A.; Jordan, K.; Schlaepfer, I.R. Targeting Fat Oxidation in Mouse Prostate Cancer Decreases Tumor Growth and Stimulates Anti-Cancer Immunity. Int. J. Mol. Sci. 2020, $21,9660$. [CrossRef]

200. Suckow, M.A.; Gutierrez, L.S.; Risatti, C.A.; Wolter, W.R.; Taylor, R.E.; Pollard, M.; Navari, R.M.; Castellino, F.J.; Paoni, N.F. The Anti-Ischemia Agent Ranolazine Promotes the Development of Intestinal Tumors in APC(-/+) Mice. Cancer Lett. 2004, 209, 165-169. [CrossRef]

201. Guzel, R.M.; Ogmen, K.; Ilieva, K.M.; Fraser, S.P.; Djamgoz, M.B.A. Colorectal Cancer Invasiveness in Vitro: Predominant Contribution of Neonatal Nav1.5 under Normoxia and Hypoxia. J. Cell. Physiol. 2019, 234, 6582-6593. [CrossRef] [PubMed]

202. Cappetta, D.; Esposito, G.; Coppini, R.; Piegari, E.; Russo, R.; Ciuffreda, L.P.; Rivellino, A.; Santini, L.; Rafaniello, C.; Scavone, C.; et al. Effects of Ranolazine in a Model of Doxorubicin-Induced Left Ventricle Diastolic Dysfunction. Br. J. Pharmacol. 2017, 174, 3696-3712. [CrossRef] [PubMed]

203. Riccio, G.; Antonucci, S.; Coppola, C.; D’Avino, C.; Piscopo, G.; Fiore, D.; Maurea, C.; Russo, M.; Rea, D.; Arra, C.; et al. Ranolazine Attenuates Trastuzumab-Induced Heart Dysfunction by Modulating ROS Production. Front. Physiol. 2018, 9, 38. [CrossRef] [PubMed]

204. Minotti, G.; Menna, P.; Calabrese, V.; Greco, C.; Armento, G.; Annibali, O.; Marchesi, F.; Salvatorelli, E.; Reggiardo, G. Pharmacology of Ranolazine versus Common Cardiovascular Drugs in Patients with Early Diastolic Dysfunction Induced by Anthracyclines or Nonanthracycline Chemotherapeutics: A Phase 2b Minitrial. J. Pharmacol. Exp. Ther. 2019, 370, 197-205. [CrossRef]

205. Aldakkak, M.; Stowe, D.F.; Camara, A.K.S. Safety and Efficacy of Ranolazine for the Treatment of Chronic Angina Pectoris. Clin. Med. Insights Ther. 2013, 2013, 1-14. [CrossRef]

206. Caron, J.; Libersa, C. Adverse Effects of Class I Antiarrhythmic Drugs. Drug Saf. 1997, 17, 8-36. [CrossRef]

207. MacNeil, D.J. The Side Effect Profile of Class III Antiarrhythmic Drugs: Focus on d,1-Sotalol. Am. J. Cardiol. 1997, 80, 90G-98G. [CrossRef]

208. Park, H.-S.; Kim, Y.-N. Adverse Effects of Long-Term Amiodarone Therapy. Korean J. Intern. Med. 2014, 29, 571-573. [CrossRef]

209. Southard, R.A.; Blum, R.M.; Bui, A.H.; Blankstein, R. Neurologic Adverse Effects of Ranolazine in an Elderly Patient with Renal Impairment. Pharmacotherapy 2013, 33, e9-e13. [CrossRef]

210. Eworuke, E.; Welch, E.C.; Tobenkin, A.; Maro, J.C. Use of FDA's Sentinel System to Quantify Seizure Risk Immediately Following New Ranolazine Exposure. Drug Saf. 2019, 42, 897-906. [CrossRef]

211. Zagelbaum, N.K.; Mondal, P.; Frishman, W.H.; Yandrapalli, S. Ranolazine Induced Delirium as a Rare Side Effect. Am. J. Ther. 2018, 25, e700-e701. [CrossRef] [PubMed]

212. Abdallah, H.; Jerling, M. Effect of Hepatic Impairment on the Multiple-Dose Pharmacokinetics of Ranolazine Sustained-Release Tablets. J. Clin. Pharmacol. 2005, 45, 802-809. [CrossRef] [PubMed]

213. Pham, D.Q.; Mehta, M. Ranolazine: A Novel Agent That Improves Dysfunctional Sodium Channels. Int. J. Clin. Pract. 2007, 61, 864-872. [CrossRef] [PubMed]

214. Reddy, B.M.; Weintraub, H.S.; Schwartzbard, A.Z. Ranolazine: A New Approach to Treating an Old Problem. Tex. Heart Inst. J. 2010, 37, 641-647.

215. Fihn, S.D.; Gardin, J.M.; Abrams, J.; Berra, K.; Blankenship, J.C.; Dallas, A.P.; Douglas, P.S.; Foody, J.M.; Gerber, T.C.; Hinderliter, A.L.; et al. 2012 ACCF/AHA/ACP/AATS/PCNA/SCAI/STS Guideline for the Diagnosis and Management of Patients with Stable Ischemic Heart Disease: A Report of the American College of Cardiology Foundation/American Heart Association Task Force on Practice Guidelines, and the American College of Physicians, American Association for Thoracic Surgery, Preventive Cardiovascular Nurses Association, Society for Cardiovascular Angiography and Interventions, and Society of Thoracic Surgeons. Circulation 2012, 126, e354-e471. [CrossRef]

216. Masters, J.C.; Shah, M.M.; Feist, A.A. Drug Interaction between Sirolimus and Ranolazine in a Kidney Transplant Patient. Case Rep. Transplant. 2014, 2014, 548243. [CrossRef]

217. Zack, J.; Berg, J.; Juan, A.; Pannacciulli, N.; Allard, M.; Gottwald, M.; Zhang, H.; Shao, Y.; Ben-Yehuda, O.; Jochelson, P. Pharmacokinetic Drug-Drug Interaction Study of Ranolazine and Metformin in Subjects with Type 2 Diabetes Mellitus. Clin. Pharmacol. Drug Dev. 2015, 4, 121-129. [CrossRef]

218. Jerling, M.; Huan, B.-L.; Leung, K.; Chu, N.; Abdallah, H.; Hussein, Z. Studies to Investigate the Pharmacokinetic Interactions between Ranolazine and Ketoconazole, Diltiazem, or Simvastatin during Combined Administration in Healthy Subjects. J. Clin. Pharmacol. 2005, 45, 422-433. [CrossRef] 